\title{
The Seagrass Holobiont: What We Know and What We Still Need to Disclose for Its Possible Use as an Ecological Indicator
}

\author{
Chiara Conte ${ }^{1,2} \oplus$, Alice Rotini ${ }^{3}$, Loredana Manfra $^{3,4}$, Marco Maria D'Andrea ${ }^{2} \oplus$, Gidon Winters ${ }^{5,6} \oplus$ and \\ Luciana Migliore $2, *$ (D)
}

1 PhD Program in Evolutionary Biology and Ecology, University of Rome Tor Vergata, 00133 Rome, Italy; chiara.conte@students.uniroma2.eu

2 Department of Biology, University of Rome Tor Vergata, 00133 Rome, Italy; marco.dandrea@uniroma2.it

3 Italian Institute for Environmental Protection and Research (ISPRA), via Vitaliano Brancati 48, 00144 Rome, Italy; alice.rotini@isprambiente.it (A.R.); loredana.manfra@isprambiente.it (L.M.)

4 Department of Marine Biotechnology, Stazione Zoologica Anton Dohrn, Villa Comunale, 80121 Naples, Italy

5 The Dead Sea-Arava Science Center (ADSSC), Masada 86910, Israel; wintersg@adssc.org

6 Eilat Campus, Ben-Gurion University of the Negev, Eilat 88100, Israel

* Correspondence: luciana.migliore@uniroma2.it

check for updates

Citation: Conte, C.; Rotini, A.;

Manfra, L.; D'Andrea, M.M.; Winters,

G.; Migliore, L. The Seagrass

Holobiont: What We Know and What We Still Need to Disclose for Its

Possible Use as an Ecological

Indicator. Water 2021, 13, 406.

https://doi.org/10.3390/w13040406

Academic Editor: Manel Leira

Received: 30 December 2020

Accepted: 29 January 2021

Published: 4 February 2021

Publisher's Note: MDPI stays neutral with regard to jurisdictional claims in published maps and institutional affiliations.

Copyright: (c) 2021 by the authors. Licensee MDPI, Basel, Switzerland. This article is an open access article distributed under the terms and conditions of the Creative Commons Attribution (CC BY) license (https:// creativecommons.org/licenses/by/ $4.0 /)$.
Abstract: Microbes and seagrass establish symbiotic relationships constituting a functional unit called the holobiont that reacts as a whole to environmental changes. Recent studies have shown that the seagrass microbial associated community varies according to host species, environmental conditions and the host's health status, suggesting that the microbial communities respond rapidly to environmental disturbances and changes. These changes, dynamics of which are still far from being clear, could represent a sensitive monitoring tool and ecological indicator to detect early stages of seagrass stress. In this review, the state of art on seagrass holobiont is discussed in this perspective, with the aim of disentangling the influence of different factors in shaping it. As an example, we expand on the widely studied Halophila stipulacea's associated microbial community, highlighting the changing and the constant components of the associated microbes, in different environmental conditions. These studies represent a pivotal contribution to understanding the holobiont's dynamics and variability pattern, and to the potential development of ecological/ecotoxicological indices. The influences of the host's physiological and environmental status in changing the seagrass holobiont, alongside the bioinformatic tools for data analysis, are key topics that need to be deepened, in order to use the seagrass-microbial interactions as a source of ecological information.

Keywords: seagrass holobiont; ecological indicators; microbial indicators

\section{Introduction}

Seagrasses are marine angiosperms that returned from the land to the marine environment 60-90 MYA in multiple events, resulting in a paraphyletic group composed of four families, three of which include only marine species [1]. Seagrasses are widely distributed in coastal waters all over the world (except Antarctica), from very shallow to $90 \mathrm{~m}$ depth [2,3]. Considered as ecosystem engineers (sensu Wright and Jones [4]), seagrasses form extensive meadows, which are the foundation of complex systems. These meadows provide key ecosystem services [3], i.e., natural processes or components that benefit human needs [5]. The three-dimensional structure of seagrass meadows provides critical habitats for many organisms and also serves as a nursery ground for juvenile stages of many species, including economically important species of finfish and shellfish [6-8]. In addition, seagrasses stabilize soft sediments and stock large quantities of $\mathrm{CO}_{2}$ as biomass and dead organic matter (blue carbon), contributing to the mitigation of anthropogenic emissions $[3,9,10]$.

Despite the ecological and economic importance of seagrass beds, an increasing number of reports have documented the ongoing loss of seagrass biomass in several 
countries, with a global decline rates estimated at $2-5 \%$ per year [11]. Most of these losses have been associated with human-driven pressures, including increased nutrient and sediment runoff, pollution, hydrological alterations, invasive species, commercial fishing or aquaculture practices. Not only do these pressures continue to threaten seagrass meadows, but they have also already shown to have caused large seagrass losses and regression worldwide, affecting entire ecosystems with a bottom up effect [12-14]. Despite the recent slowing down of these trends, mainly of fast-growing species [15], the overall worldwide trend is still the decline or deterioration. These ongoing declines are particularly high for the more slow-growing seagrasses (e.g., Posidonia oceanica; the foundation of one of the most valuable Mediterranean ecosystems), where reductions and a lack of recovery cause severe losses of some of the ecosystem services provided, since their ecological functions and services cannot be replaced by the fast growing seagrass species $[5,16]$.

To mitigate seagrass losses, it is essential to detect the environmental changes and seagrass stressors, prior to the decline (sometimes irreversibly) in local meadows occurs. The current challenge, thus, is the development and the combination of sensitive and measurable descriptors of seagrass stress, able to assess seagrass ecological state and its alterations. This will help to prevent the decline and enhance our understanding of seagrass global processes and threats, further supporting the development of effective monitoring and integrated management programs [17-20].

To date, seagrass descriptors have focused on different biological organization levels from the population to the individual levels, such as shoot density, alongside biochemical and genetics descriptors $[19,20]$. The time of response of such indicators to stressors generally increases with the structural complexity, while their specificity decreases [18]. With most the descriptors used these days in seagrass monitoring programs being based on the slow responding population level (e.g., species composition, percent of cover, density, etc.), there is a growing interest in shortening the time of response by identifying early warning indicators. Recent studies [21-32] have evaluated the pivotal role of the microbial community associated with seagrass in their physiology and ecology, assessing their symbiotic relationships and the variability of microbes according to the environmental/host conditions, arguing that the host associated microbes could be a sensitive monitoring tool and ecological indicator. In fact, as microbial communities respond rapidly to environmental disturbance, monitoring their composition could represent an early indicator of environmental stress $[21,22,24,25,29,31,32]$. Despite the encouraging results of the abovementioned studies, the comprehension of the seagrass associated microbial community variation according to the host conditions is still far from being clear.

The seagrass-microbes associations are the result of a selective process involving both the seagrass microenvironment availability - depending on the host ecological/physiological conditions in response to the environment, and the metabolic capabilities of the microbes. The intimate relationship between the host and its associated microorganisms has led to considering them as a complex single super-organism that jointly responds to environmental changes as a functional complex unit, called the holobiont [33]. This perspective significantly changes the way of thinking of a living-organism and may provide important insights into the organism condition and, consequently, into the potential use of associated microbes as a source of ecological information.

While several seagrass-microbe interactions, mainly studied as belowground functional processes, have been identified (see Section 1.2); a unified point of view about the factors implicated in the settling, composition and spatial-temporal variation of the associated microbial communities, is still missing. One of the main questions that need addressing is whether seagrass species-specificity can be hypothesized. In other words, does each seagrass species harbors its own specific taxonomic and/or functional microbiota across different sites, or is the seagrass microbiota shaped by the environmental conditions and follow a common pattern in different seagrass species growing in the same habitat. This is a pivotal point that would give insights into both the seagrass' capability to select their hosts and the ecological meaning of variations in the microbial component of the 
seagrass holobiont: elucidating the key host-microbe interactions may provide guidance for seagrass managing and/or restoration [34].

Often, different studies found heterogeneous results on the epiphytic microbial taxonomic composition; in some cases species-specific differences were found [35-37], while in others comparable microbial communities were found associated with different seagrass species from the same site $[27,38,39]$. The species-specificity of the microbial profile has been related to specific biochemical properties, while the comparable microbial communities were mainly attributed to the local environmental conditions.

The aim of this work is to review all the information available to date that can support the potential use of associated microbes as early warning indicators of seagrasses and marine environment ecological status. The following paragraphs summarize the stateof-the-art on seagrass holobiont, focusing on the aspects that need to be deepened in order to develop an integrated seagrass microbiome-based index. These include, from our point of view, the associated microbes' variability according to the host species/host physiology/environmental conditions and the bioinformatics aspects, which is crucial to have reliable and homogeneous data.

\subsection{The Holobiont Concept}

Host-microbes interactions play crucial roles in biological and ecological functions, thus, organisms are better considered as a network of interactions between the host and all the associated microorganisms (bacteria, fungi and viruses), with which the host establishes transient or lasting complex relationships [40-42]. The host and the entirety of microorganisms living in/on its tissues represent a complex functional unit, the holobiont [33].

Lynn Margulis [43-45] was the first to emphasize the role of the symbiosis, and in particular the endosymbiosis, as an evolutionary trajectory. Her studies are considered the starting point of this research field, despite similar ideas having already circulated years before, due to the less known German scientist Meyer-Abich [46]. Working mostly on microbial communities of corals, Zilber-Rosenberg and Rosenberg implemented this concept, considering the holobiont as an additional organismal level on which natural selection may operate $[47,48]$, and defining the hologenome as the integration of the host genome with the gene pool of the associated microorganisms [47,49-51]. In this review, we will focus on the interactions between the host (seagrass) and the bacterial partners but, of course, also other microorganisms may contribute to the holobiont.

The role of the host-microbe interactions, as an evolutionary driving force, is still unclear [48,50-52]; however, the importance of considering such interactions in the host physiology and ecology is indubitable [53,54]. In fact, the holobiont changes according to the environmental changes and maintains the host-microbes homeostasis, and its disruption may lead to pathologic conditions [55-58]. For instance, the rapid changes in the microbiota, in terms of changing community structure and composition, mutations or horizontal gene transfer, facilitate the holobiont adaptation to the continuous and unpredictable changing environmental conditions [24,52,54].

Thus, the holobiont is a theoretical and experimental framework to study the interactions between the host and its associated microbial communities in all types of ecosystems [53], from humans [59-61] to animals and plants [54,62-69].

In terrestrial plants, the role of microbes in plants' growth, development, nutrient uptake and defense mechanisms has been widely assessed, and important mutualistic, commensal and pathogenic interactions have been observed [54,67-69]. For instance, rhizobial bacteria fix nitrogen within the root nodules of their symbiotic plant partner, providing many plant species with an essential source of bioavailable nitrogen [70,71]. Among marine species, the holobiont concept has been applied to corals, sponges and seaweeds [33,63-66,72-74]; in many cases the variation of the associated microbiota was found as a response to environmental stress, leading to dysbiosis (microbial imbalance) $[57,58,75-77]$. Recently, the seagrass holobiont has been explored $[24,25,78-80]$, 
with interesting but contrasting outcomes regarding the factors involved in shaping these interactions, as summarized in the next paragraphs (Sections 1.2 and 2).

\subsection{The Seagrass Holobiont}

The seagrass holobiont is made up of the plant and its associated microbial communities: seagrass harbor different and rich epiphytic microbial communities on their above- (leaves, otherwise called phyllosphere) and belowground (rhizomes and roots, otherwise called rhizosphere) plant parts [78-80], but also a more intimate association (endophytes) has been proposed for microbes and roots tissues [81]. Seagrass and microbes may establish symbiotic relationships [78-81]: for instance, microbes are known to: (i) enhance the nutrients and vitamins availability, which are limiting factors for seagrass growth and primary production [30,82-88], (ii) enhance seagrass growth, by producing hormone-like compounds $[27,88]$ and (iii) protect seagrass roots, by detoxifying the rhizosphere $[26,29,85]$.

A remarkable difference among the microbial communities associated with the aboveand belowground seagrass plant compartments has been found $[24,25,31,37,39]$. This is not surprising, as the two parts are positioned in very different environments in terms of light, oxygen, redox gradient and carbon availability. Furthermore, the seagrass plants themselves establish diverse chemical microenvironments: leaves release organic carbon, producing organic carbon enriched habitats [78]; roots supply their surrounding sediment with oxygen, creating aerobic microzones in the anoxic sediment and redox gradients that lead to phosphorus and iron mobilization into the rhizosphere [26,29,84]. The aboveground compartment is colonized by a large variety of generalist, aerobic organo-heterotrophic taxa, able to degrade common plants' polymers, waste compounds and biofilm $[25,78]$. The belowground compartment, due to the partial presence of oxygen, harbors both anaerobic and aerobic microorganisms, such as chemolithotrophic, sulfur-oxidizing and nitrogenfixing microorganisms [25-28,78]. Due to the radial loss of oxygen and to the release of exudates $[26,89,90]$, the belowground compartment stimulates a selective microbial growth and in turn, receives benefits from bacterial metabolism [91,92]. Few studies have analyzed the rhizomes as a separate plant part $[37,93]$ finding that it harbors unique microbial communities, although some microbial groups are shared with roots and sediment. As a final point, Hurtado-McCormick et al. [93] hypothesized that the local physiological activities of the seagrass may produce a further differentiation of the colonized surfaces in microhabitats. They did not find significant differences among leaves' microhabitats (i.e., upper or lower side of the leaf), although they highlighted clear differences among rhizome/roots colonizers, probably depending on local selective environmental conditions (mentioned above).

The genetic/metabolic versatility of microbes is one of the key points of the plant/ microbes association $[27,94,95]$. Microbe versatility contributes to the plant nutrient supply, acting in the sulfur and nitrogen cycles $[85,91,92,96,97]$; this represents a benefit for seagrasses and allows us to infer, which are the main metabolic patterns that are taking place around the roots of seagrasses. For instance, the nifH gene (marker of nitrogenase activity) that demonstrates the presence of nitrogen-fixing bacteria, found in the microbial community associated with roots of P. oceanica, was found to belong to sulfur-oxidizing or sulphate-reducing bacteria [92], suggesting that the nitrogen-fixing bacteria may play different roles, other than being an important source of nitrogen for seagrasses [95-99]. Similarly, a metagenomic study on the bacteria associated with Zostera marina's roots highlighted the presence of several genes involved in sulfur oxidation, nitrate reduction and carbon fixation $[27,28]$.

Seagrass sediments contain organic matter due to plant debris, benthic or sink dead organisms that sunk to the bottom, and to root exudates [80]. In sediments, microbial mineralization can be either aerobic, in the thin layers of the upper sediment and around the seagrass' oxygen leaking young root tips, or anaerobic in deepest sediment layers, beyond the effect of the seagrasses' roots $[26,99,100]$. The anaerobic decomposition involves sulfate- 
reducing bacteria and leads to the accumulation of phytotoxic $\mathrm{H}_{2} \mathrm{~S}$ into the sediment, a mechanism was suggested to be responsible for historical events of wide seagrasses die-off $[29,85,101]$. Seagrasses tolerate low concentration of $\mathrm{H}_{2} \mathrm{~S}[85,101,102]$, and they overcome its toxicity by translocating the photosynthetically produced oxygen, from the leaves to the rhizosphere supporting local spontaneous $\mathrm{H}_{2} \mathrm{~S}$ reoxidation [103,104]. This allows the thriving of sulphate-oxidizing bacteria $[26,28,89]$, found to be less abundant in low-light conditions [29].

Diazotrophic bacteria, which enhance seagrass nitrogen availability [30,86,98,105-107], have been found in both the above- and the belowground seagrass tissues and are more abundant in vegetated sediment than in the bare one $[95,107]$. For instance, cyanobacteria were found to be more abundant on seagrass leaves from oligotrophic environments [35,107], and Tarquinio et al. [30] demonstrated that leaves of the temperate seagrass Posidonia sinuosa with associated microbes, accumulate more nitrogen than those devoid of microorganisms. In this laboratory study, Tarquinio et al. [30] incubated seagrass leaves with amino acids labeled with stable isotope ${ }^{15} \mathrm{~N}$ and found that the marked amino acids were assimilated by the associated microbes and by plants, but not by plants without microorganisms. This demonstrated the active role of seagrass associated microbiota both in supplying nitrogen to plants and in amino acid mineralization.

Nitrogen fixing bacteria play another important role in the seagrass holobiont, being also involved in the phytotoxic sulfate-reduction, a key-role in organic matter mineralization. The seagrass release of photosynthates translocated from roots to the rhizosphere sustains epibionts associated to their tissues or in the close surrounding environment $[26,29,89,107]$, suggesting a mutualistic relationship between the seagrass host and its diazotrophic bacteria, and the role of these microorganisms in maintaining seagrass health [30,32].

Another key point in the holobiont dynamics is that seagrass might select their epiphytes and contrast pathogens, by producing antifouling and antimicrobial compounds [108-110]. On the other hand, even microbes produce antimicrobial compounds and may enhance seagrass defenses [27,110-115]. In fact, they produce compounds to control biofilm forming-bacteria [112-118] or lytic enzymes, as agarases and carrageenases, which degrade galactose-based algal polymers [119], potentially controlling the growth of microalgal biofilm [27]. For instance, members of the genus Bacillus and Virgibacillus found associated with the tropical seagrasses Thalassia hemprichii and Enhalus acoroides were shown to exert antifouling activities against biofilm-forming bacteria [117,118]. In addition, Actinobacteria, commonly found associated with seagrass $[27,31,35,39,95,99,112,117]$, has been considered as a source of bioactive natural compounds [112]. A further important interaction in the holobiont regards the capability of microbes to break down phytotoxic compounds $[26,27,32,78,79,104]$, contributing further to seagrass health.

Thus, the microenvironments of seagrass surface could be a selective substrate for microbial growth, although this hypothesis deserves further investigation. Research in this field will surely provide new insights into plant ecology and associated microbial community dynamics, an important step towards seagrass monitoring and conservation [32,34,79].

A last critical point for the holobiont comprehension is to understand the process of microbial colonization of the seagrass compartments. It must rely on the environmental microbial pool, as so far no other microbial sources have been detected [120]. This colonization process may follow different pathways: microbial communities associated with leaves generally mirror those present in the surrounding seawater column, while microbial communities associated with the rhizome/root usually strongly differs from the sediment microbial community [120].

A recent study by Kohn et al. [121] focused on the variation of microbial communities on the leaves of the same Posidonia oceanica plants over time: the authors showed that a macroscopically different biofilm is found in young and older leaves, with increased diversity in older leaves, but with very similar taxonomic compositions. The influence of age on root-associated microbial biofilm was investigated but no clear trends were 
found [22,122]. However, the colonization time is probably an important factor shaping the seagrass holobiont, and deserves further attention.

Looking at the ecosystem level, interactions among seagrasses and microorganisms can directly influence large-scale biogeochemical processes, including coastal carbon sequestration [123-133], the so-called blue carbon [124]. Seagrass ecosystems are significant carbon sinks, as both living plant biomass and recalcitrant dead organic matter, and the degradative activity of the sediment microbial communities control the amount of sequestered carbon [128,131]. Recent studies showed an increased mineralization rate of organic carbon in sediments as a response to eutrophication and warming seawater temperatures. In fact, both eutrophication and warming seawater temperatures may stimulate microbial metabolism and speed-up the mineralization processes, enhancing $\mathrm{CO}_{2}$ release within the water column $[126,129,131,132,134]$. Contrasting results were found by investigating whether the nutrient input stimulates the mineralization process in vegetated sediments $[129,131]$. These results suggest the co-occurrence of other factors that are able to drive the microbial response to increased nutrient availability [131]. On the contrary, rising temperatures seem to have a significant effect on the aerobic mineralization of organic carbon, but a negligible effect on both the anaerobic mineralization and the recalcitrant seagrass dead tissue mineralization, as debris of rhizomes and roots [126,131-134]. Thus, the aerobic mineralization of exposed buried carbon (as in the case of sediment resuspension by trawling) may reduce the carbon sink capacity of seagrass dead organic matter, through increased microbial abundance and speed-up of the mineralization process [133,134]. Hence, seagrass-microbes interactions may clearly affect ecosystem processes and these interactions, usually evaluated at small scales, have to be upscaled and evaluated even at a wide seascape. To this end, the study of seagrass holobiont variations in the field and/or under controlled laboratory conditions is pivotal to point out which factors shape and regulate these interactions. Such studies could contribute to seagrass monitoring and conservation efforts.

\subsection{A Case Study: The Halophila stipulacea Holobiont}

Halophila stipulacea is a small fast growing tropical seagrass [3], native to the Red Sea, Persian Gulf and the Indian Ocean (Figure 1a) [135]. Following the opening of the Suez Canal, it settled in the Mediterranean Sea 150 years ago as a Lessepsian migrant [105,135-138], where it remained in insulated, small populations across the eastern part of the basin (Figure 1b). Surprisingly, in 2002, Halophila stipulacea was reported in the Caribbean Sea, where within less than two decades it spread to most of the Caribbean Island nations and has even reached the South American continent (Figure 1c) [139-144]. Unlike its limited invasion of Mediterranean, in the Caribbean H. stipulacea creates large, continuous populations often completely displacing local Caribbean seagrass species [135,139-144]. Realizing that the Caribbean Halophila situation might repeat itself in the Mediterranean Sea in the coming future, scientists have already begun to sound their alarms. Indeed, the potential threat to local biodiversity posed by $H$. stipulacea was raised by including $H$. stipulacea in the "100 Worst Invasive Alien Species in the Mediterranean" [145]. With the recent doubling of the Suez Canal (July 2015) and the warming of Mediterranean Sea-one of the basins most rapidly changing under climate change [146] - there is great concern that the so far limited population of H. stipulacea may spread. The species, in fact, is already expanding, competing with the local Cymodocea nodosa [147]. 


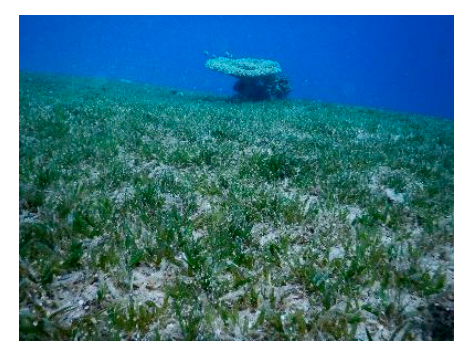

(a)

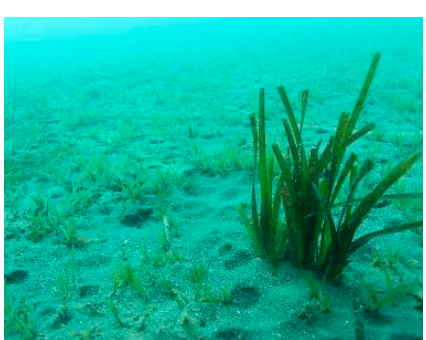

(b)

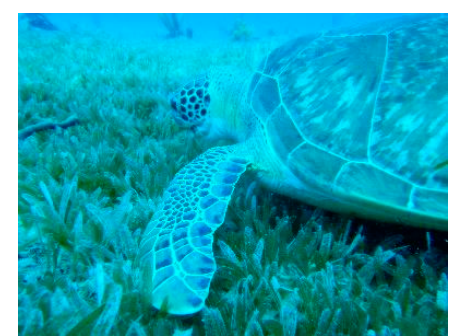

(c)

Figure 1. (a) Meadow of native Halophila stipulacea in the Red Sea, (b) shoots of invasive H. stipulacea in the eastern Mediterranean Sea mixed with shoots of the endemic Posidonia oceanica and (c) meadow of invasive H. stipulacea in the Caribbean Sea with the green sea turtle (Chelonya mydas) feeding on it. Pictures $(\mathbf{a}, \mathbf{c})$ by Gidon Winters, picture $(\mathbf{b})$ by the CMarine and Environmental Research (MER) Lab. (Limassol, Cyprus).

The invasiveness of $H$. stipulacea is probably due to its capabilities to thrive under different ecological conditions including different salinity, light and water temperature [148-151], being able to easily adapt its morphophysiological parameters to changing environmental conditions $[24,25,105,135,150,152-160]$. H. stipulacea is also able to modify its morphology: it shows increasing leaf size along depth gradients $[25,152-154,156,157,159,160]$ and small leaf size (width and length) under high light levels and/or high temperature and hydrodynamics $[25,152,155]$. The plant can also rapidly adjust its photosynthetic responses $[24,25,135,148,159,160]$ and the synthesis of secondary metabolites, such as total phenols $[24,25,153]$ according to environmental conditions. Even the epiphytic bacterial community associated with $H$. stipulacea varies across environmental conditions. This suggests a crucial involvement of the seagrass-associated microbiome in the host physiological functions of the host and a potential contribution to the adaptive and invasive capabilities of this seagrass species [24,25].

The microbial community associated with $H$. stipulacea has been studied, so far, only in its native area (Red Sea) $[24,25,37,105,161,162]$. Some "historical" studies were carried out with culture-dependent analyses [37,105]; these studies highlighted the differences of the bacterial community associated with different plant compartments, with higher density of heterotrophic microbes found on its leaves. Moreover the leaf's microbial community followed the seawater microbial community seasonal variation [37], and different nitrogen-fixing microbes on the leaves (light dependent diazotrophic bacteria that performed non-oxygenic photosynthesis), on the upper-rhizomes (Cyanobacteria) or on the roots (heterotrophic diazotrophs) [105]. This suggests that $H$. stipulacea associated microbes can fix nitrogen in different conditions (and plant compartments), thus supplying the plants with the nitrogen needed, a potential evolutionary advantage ascribable to the seagrass-microbial symbiosis.

Weidner et al. [161,162] identified on the leaves of H. stipulacea a diverse assemblage of bacteria mainly belonging to Alpha- and Gamma-Proteobacteria, by using a restriction fragment length analysis termed ARDRA (amplified rDNA restriction analysis).

More recent studies $[24,25]$ applied the analyses of the $16 \mathrm{~S}$ rDNA amplicons (obtained by 454-pyrosequencing or Illumina sequencing) to characterize the taxonomic composition of the microbial epiphytic communities associated with H. stipulacea alongside measurements of seagrass morphological and biochemical indexes (e.g., leaf morphometrics, pigments and phenols content), in different ecological conditions. In the Gulf of Aqaba, under different anthropogenic pressure (i.e., coastal urbanization, fish farming activities, commercial maritime facilities, etc.), depths, topography and hydrodynamics (adaptation at small spatial scale) H. stipulacea was found to modulate: (i) leaf morphology and photosynthetic pigment content according to light availability, depth and hydrodynamics; (ii) total phenol content according to the anthropogenic pressure (and to irradiance) and (iii) the microbial communities according to local environmental conditions and plant compartments. A high incidence of Gammaproteobacteria and Bacteroidetes was found in light-limiting conditions, 
while Cyanobacteria and Rhodobacteraceae thrived in conditions of high light availability and hydrodynamics. The Alphaproteobacteria were dominant on leaves while Alfa-, Gamma- and Delta-Proteobacteria were equally distributed on roots. The less represented microbial groups were specific to each site, suggesting that the microbial community associated with $H$. stipulacea was made up of a conserved main core (i.e., a "core microbiome" shared across all sites) and a highly variable small component that may help plants to cope locally with environmental pressure (i.e., a local environmental fingerprint). The Alphaproteobacteria class, in particular the Rhodobacteraceae family, may be abundant on the leaves due to their abundance in the water column and in oligotrophic coastal waters $[163,164]$ and its capability to cope with variations of salinity, oxygen saturation, $\mathrm{pH}$, nitrate concentration and temperature $[165,166]$.

The studies reviewed above found some common points of the H. stipulacea holobiont in the Red Sea. All of them highlighted a marked difference between the microbial communities associated with above and the belowground plant parts, as assessed in other seagrass microbiota studies. Moreover, other studies [24,25,161,162] found common microbial groups associated with this seagrass. Among these are mentioned the Alphaproteobacteria class and in particular the Rhodobacteraceae family, Gamma- and Delta-Proteobacteria and low abundance of Actinobacteria; these data support the existence of a local microbial core, where microbial groups could play crucial roles in $\mathrm{H}$. stipulacea functions in that environment [25,167]. For example, it has already discussed the potential role of Actinobacteria group in providing antimicrobial compounds and the capability of members of the Pseudomonas genus to produces antifouling compounds and the presence of nitrogen fixing bacteria, like Planctomycetes [105], or denitrifying microbes as Pseudomonadaceae [168].

Studies by Mejia et al. [24] and Rotini et al. [25], relating the microbial analyses to different environmental conditions and to seagrass ecophysiological analyses, provided insights into the holobiont functionality. For instance, the co-occurrence increase of leaf phenol content and leaf microbial abundance, suggests a role of phenols in mediating the seagrass-microbial interaction or the induction of phenols production as a chemical defense against microbes. H. stipulacea, in fact, has high content of flavones [169-172] and phenols $[24,25]$. These classes of compounds are secondary metabolites known to be involved in plant defense and in regulating microbial interactions $[20,171,173]$.

Collectively, the discussed studies build up a useful baseline of the symbiotic relationships between microbes and H. stipulacea, offering new tools to understand the plasticity and the adaptive capabilities of this species. On the other hand, these studies suggest that $H$. stipulacea can be a good model organism to investigate in depth the seagrass holobiont structure and functionality.

Further studies are needed to clarify the seagrass-microbial interaction and, in particular, to clarify the variation of the seagrass holobiont related to the seagrass ecophysiology and environmental conditions. Studies in this direction are in progress on the invasive H. stipulacea, in both the Mediterranean and the Caribbean Seas, in order to evaluate the microbial role in its invasiveness potential. Hopefully, this research will place the seagrass holobiont into the wider frame of the ecosystem processes.

\section{Hinges of the Seagrass Holobiont Composition}

\subsection{Plant Species}

Regarding the role of the host seagrass species, previous studies have resulted in contrasting evidence. On the one hand, studies have shown that within the same geographical site, microbial communities on different seagrass species were similar $[27,38,39]$. On the other hand, studies have also shown that there were significant differences in terms of microbial community composition between different seagrass species growing side by side $[29,35-37,174,175]$. In parallel, differences in the composition of microbial communities were also found in the same seagrass host species growing at different sites $[24,25,120,176-178]$. These contrasting results may depend on plant structure (i.e., plant habit; [36,175]), composition of meadows (i.e., mixed or monospecific stands; $[27,35]$ ), 
sampling time (i.e., season, daytime; $[31,36])$ or environmental/host conditions (i.e., light, seawater acidification; [23,29]), all major factors influencing the microbiota composition.

The species-specificity usually does not result from the overall community profile but from the less abundant components $[35,174,175]$ that could highlight specific functional associations [39].

The prevalence of bacterial taxa associated with different species in the same site $[27,38,175,179]$ or with the same seagrass species growing in different sites/conditions $[24,25,93,120]$ is often defined as the "microbial core community". Probably, instead of a generally important seagrass-microbial core, a local core can be identified [25,31,167], playing environmentally specific functions [93]. The identification of the core and the changing components of the microbial partners is a key-point in understanding the dynamics of the holobiont.

As a general rule, the aboveground associated microbial communities are similar to those found in the surrounding seawater $[120,176]$, and were found to be more variable compared with the microbial communities growing on the belowground plant compartments $[24,25,27,31]$, highlighting the importance of environmental fluctuations (more probable in seawater than in sediment) in eroding the stability of bacterial community assembly [25]. The high variability of these communities may depend on different factors and results in less marked species-specific differences. However, other studies [27,179] found clear differences between the leaf-associated and the seawater community, suggesting a host-driven selection in the shaping of the associated communities. Probably, both host-driven selection and random microbial recruitment simultaneously operate in determining the structure and composition of the microbiota. Hence, deepening our knowledge on the relative contribution of these components, with wide comparison studies in different seagrass host species and environmental conditions, will allow us to understand and predict whether and how an environmental change might affect the microbial community, the seagrass host or the entire holobiont.

The belowground associated microbial communities were found to be less variable than those associated with the aboveground plant compartment $[24,25,27,31]$. The colonization of the belowground plant compartment is assumed to depend on both the chemical microenvironments $[29,89]$ and the age or density/structure of the roots $[96,99,122]$. Cúcio et al. [38] found similarities among seagrass rhizosphere colonizers in three seagrass species (Z. noltei, Z. marina and C. nodosa) from the same location (assumed to contain similar sediment type and conditions), suggesting that seagrass are able to select their epiphytes, as a functionally oriented and not a seagrass species-specific selection. On the contrary, Martin et al. [29] suggested that different seagrasses from the same site have different root microbiota due to seagrass the species-specific root exudates. Similarly, Garcias-Bonet et al. [175] found different bacterial communities in two different seagrass species rooted in the same site, suggesting that both the host-species and the environmental conditions contributed to shape the microbial community.

Species-specific root-associated microbial communities have been found also in the same seagrass species from different sites $[24,25,120]$, leading to the suggestion that future studies might reveal a wide and potentially even a worldwide similarity among speciesspecific belowground microbial communities [120]. This hypothesis was confirmed by the H. stipulacea case study already discussed $[24,25,179]$ (see Section 1.3$)$, where a high incidence of Alphaproteobacteria were found in both native (Northern Gulf of Aqaba) [24,25] and invasive sites (Eastern Mediterranean Sea) [179]. These results might suggest that microbial colonization of seagrass roots could be mainly driven by host metabolism rather than by response to local environmental conditions $[26,29,31,89,103]$.

The main microbial groups found associated with the belowground seagrass compartment are those involved in the sulfur and/or nitrogen cycles [26,28,29,32,89,91,95,97-99,180], like Gamma-, Alpha-, Delta- and Epsilon-Proteobacteria. Members of these classes are able to produce antimicrobial compounds, such as those belonging to the Vibrionaceae family (Gammaproteobacteria) [181] or Actinobacteriaceae (Gammaproteobacteria) [112,182] and may potentially affect the microbial community compositions [31,112]. 
These contrasting outcomes about the relations between microbes and seagrass species do not exclude each other. The microbial colonization of seagrass may follow different successive patterns, in which "suitable" bacteria are chosen among those available in the local pools (depending on environmental conditions) and act as pioneer colonizers. Some of these species can be promoted/hindered by the host-bacteria selection process, according to the different host traits [183,184]. Moreover, according to Ugarelli et al. [39], specific differences in microbial colonizers may be overlooked as the most abundant families (generalist heterotrophic groups) are shared by different seagrass species, while the speciesspecific associated microbes may represent a minor component of the associated microbial community.

Although they are physically and biochemically/physiologically interconnected, the above- and belowground plant parts are morphologically different and exposed to different conditions, thus it is assumed that they are differently colonized. In terrestrial plants, soil microbes colonize roots and then migrate to the aboveground parts [68]; this has never been assessed in seagrass, even if a bottom-up influence has been speculated. The link between the microbial communities of the two plant parts could be indirect, with microbes flowing with organic matter from the above- to the belowground plant part or into sediment; this could explain the shared microbial community components between the above- and belowground plant parts [100,125,185]. The link could be either direct: for instance, environmental changes acting on leaves may influence the physiological activity of roots, to which the microbial community promptly reacts $[29,31,103]$.

\subsection{Environmental Conditions}

Seagrasses respond to the environmental variation by changing their physiological and biochemical activity followed by changes to their morphology. The associated microbial community seems to be sensitive to either the environmental or the host's physiological changes. Compared to the belowground microbial communities, the aboveground microbial epiphytes seems to be more sensitive to the environmental changes; this might be due to: (i) the possible instantaneous variation of the environmental conditions, to which the bacterial taxonomic assembly rapidly responds, as suggested for seaweeds $[76,183,186]$, and/or (ii) event-driven patterns, which lower the probability that the first colonizers of the emerging leaf will be exactly the same for different leaf onset events [25]. Conversely, the belowground microbial epiphytes seem more conservative and sensitive to the host physiological changes [21].

Reduced light availability, for instance, alters seagrass root exudation that, in turn, changes the root microbiota composition, reducing the abundance of potentially beneficial microorganisms [29]. In roots, low light exposures increase the exudation of total dissolved organic carbon and nitrogen, as a result of fermentation products. This release is due to the metabolic shift under hypoxic condition, as belowground oxygen supply is limited by reduced photosynthetic activity [29,103]. Under natural conditions, light availability depends on seawater turbidity, but may also be affected by epiphyte coverage as well, as demonstrated by Brodersen et al. [103]: the leaf epiphyte coverage reduces the amount and quality of light radiation available for photosynthesis, reducing the plant fitness. Rotini et al. [31] showed a daily variation of the microbial community composition associated with Thalassia hemprichii: plants responded to changing irradiance with changing production of HSP60 and HSP70, and accordingly, the phyllosphere-associated microbial community shifts from Enterobacteriaceae (dominant in the morning) to photosynthetic Alphaproteobacteria (dominant in the afternoon); concurrently, a variation occurs also in the composition of the belowground microbial community.

Simulating ocean acidification, Hassenrück et al. [23] instead, analyzed the influence of the low $\mathrm{pH}$ on the microbial communities associated with Enhalus acoroides leaves due to natural $\mathrm{CO}_{2}$-vents. They found differences in the leaf associated microbial biofilm composition as a result of to the proximity of the vents, highlighting the sensitivity of leaf biofilm to environmental gradients (e.g., $\mathrm{pH}$ gradient) and due to different leaf ages, 
suggesting a potential influence of the host physiological conditions of the host, but unfortunately this last part is not discussed in the paper.

These studies highlight the coupled responses to the environmental changes of the seagrass physiology and composition of associated microbes, suggesting that this rapid microbial response deserves more attention, as it might be a sensitive and an early warning indicator of the changing plant physiological state.

In addition to being affected by their environments, seagrasses-defined as ecosystem engineers-are also able to modify their surroundings environments, including the microbial communities [84,89,95,187-192]. Indeed, vegetated sediments host high abundance of nitrogen-fixing bacteria $[95,189]$, and the seagrass rhizosphere hosts high abundance of microbial genes related to putative phosphorus and sulfur pathways [26,190]. In this perspective, the biogeochemical cycles are undoubtedly influenced by seagrass meadows, which, in turn, have been found to influence the sediment microbial taxonomic profile $[96,97,99,191,192]$, with a larger extent than environmental factors like the seasonal seawater temperature fluctuation [21]. Ettinger et al. [96] found a significant correlation between sediment microbial community structure and seagrass density, with an enrichment of microbes involved in the sulfur-cycle in the densest area of the meadow. On the contrary, Bourque et al. [188] found that the complexity of the seagrass sediment microbial community seems to be influenced by the ecological condition of the seagrass meadows that was lower in the disturbed sediment, while, similarly Sun et al. [191] found that seagrasses caused a decrease in sediment microbial diversity. Another interesting insight is the observation that the microbial community within the sediment surrounding the native Zostera capricorni is able to hinder the growth of the invasive seaweed Caulerpa taxifolia, contributing to the capacity to resist the settling of this invasive macroalgal species [192].

While the mutual influences between seagrasses and the microbial communities in their surrounding sediments have been demonstrated $[26,29,89,95,96,187,188,192]$, the relationship between seagrasses and their surrounding seawater column is less clear. Lamb et al. [193] found that the presence of seagrass reduced the potential microbial pathogens (e.g., Enterococcus spp.) in the water column and lowered the incidence of corals diseases in the coral reef neighboring these seagrass beds. However, Webb et al. [176] attributed the reduction of potential microbial pathogens within the seawater column to the location, current flow and tides (inside vs. outside the San Diego Bay), rather than to the presence of seagrasses. This discrepancy could reflect geographical differences in terms of contaminant exposure and water circulation.

Taken together, this data highlights the continuous dialogue between the abiotic factors and the living organisms' complex associations, suggesting that the microbial perspective should be considered in a much wider ecosystem scale and perspective.

\subsection{Taxonomy and Functions}

As a consequence of bacterial metabolic versatility, the taxonomic composition of the communities may be quite distinct despite their superimposable functionality. Furthermore, regardless of host species and conditions, the functional redundancy of the communities guarantees the key processes, which may be unaffected by changes in community structure $[26,167,194]$. Thus, plants may recruit microbial populations belonging to different taxa, among those available in the environment, ensuring the key functions for the holobiont [167].

However contextually, each seagrass host-type may own a specific taxonomic and functional microbial community, due to its physicochemical properties. To identify the influence of the host species on the composition of their associated microbes, Roth-Schulze et al. [194] compared surface-associated communities of different seagrass and seaweed species from different sites; they found that sample-type rather than collection time and location shaped the microbial communities, underlining the host influence in terms of taxonomic composition; however, they also found that despite the taxonomic differences, the microbial communities shared a wide range of functional capabilities. 
This suggests that seagrass epiphytic microbial community composition may depend on microbial functionality rather than taxonomy following the "lottery model" [195]. According to this model, there are several microbes that are able to play the same functional role, but during the colonization process the first colonizer is the one that eventually settles in the community $[184,194,195]$. This hypothesis was recently confirmed by Martin et al. [29] that compared the microbial community associated to seagrass roots under different light conditions and found a variation of taxonomic microbial composition, but no variation in the functional pathways of these communities. These results were made possible by using the 16S rRNA gene for the microbial taxonomic identification coupled with PICRUST software [196]. The PICRUST output gives a first insight into the functional profile of a microbial community [197]: it predicts the gene functionality of the community relating to the taxonomic profile produced by the 16S rRNA metagenomics, and the metabolic pathways of the identified taxa found into the KEGG database [198]. However, due to the paucity of available reference genomes in the database, and the huge genomic diversity of isolates belonging to the same species, it does not provide a reliable picture of the community functional profile [32].

In fact, the great majority of the studies on the seagrass associated microbial communities are based on their taxonomic identification based on $16 \mathrm{~S}$ rDNA amplicon sequencing. Analysis of the 16S rRNA gene clearly highlights the shared and unique microbial components among seagrass species or sites, allowing one to infer host and/or conditions specificity in the frame of comparative studies. However, while this type of sequencing gives insights into the potential microbial functionality, it does not reveal the actual biochemical processes active at a given moment in the community [27]; furthermore, the 16S rRNA gene amplicon sequencing techniques usually do not reach a deep classification level, and therefore are not able to provide a reliable taxonomic identification, at least for some subsets of microbes.

To cope with these issues, multiple omics-techniques have to be applied, such as the use of shotgun meta-transcriptomics or proteomics, which could provide important information necessary to gain a wider and realistic overview of the seagrass-microbes interactions. The importance of available techniques and bioinformatics tools is discussed in the next paragraph (see Section 3).

\section{Key Role of Methods in Characterizing the Seagrass Holobiont (from Classical to "Omics")}

Only a small fraction of the bacterial species can be readily cultivated in microbiology laboratories, hence, studies assessing the composition of different microbial communities, including those growing on seagrass, have gradually moved away from the culture related approaches $[37,105,199,200]$, to culture-independent molecular based techniques $[35,36,99,161,162,201]$ and, ultimately, to next-generation sequencing (NGS) approaches $[23-25,27-29,31,32,38,39,96,97,191,202]$. This paradigm change has been necessary because bacterial growth is inhibited in vitro, if crucial factors of their natural environment are not properly replicated in the laboratory. While abiotic factors (e.g., $\mathrm{pH}$, temperature, oxygen and nutrients availability, light intensities, etc.) can be quite easily replicated in vitro, biotic factors are much more difficult to mimic. In addition, evidence from culture dependent and microscopic approaches underscore a prominent role of fungi within seagrass physiology and ecology [203-205], but studies providing a wide overview of these taxa, such as those employing NGS approaches, are still incipient $[27,80,206,207]$. A similar paucity of information turns evident also considering the association of seagrass with viruses and archaea, even if, for the latter, the existence of both Euryarchaeota and Crenarchaeota in sediments associated with different Zostera spp. has been reported [203,206].

Therefore, studies aiming to decipher the complex interactions between members of a holobiont, more and more frequently employ a number of molecular based techniques, with NGS-based emerging for their ability to provide detailed snapshots of the complete structure and composition of microbial communities in a defined interval of space and time. 
Studies using target amplicon sequencing, especially those focused on the ribosomal DNA (mainly $16 \mathrm{~S}$ for prokaryotes, $28 \mathrm{~S}$ or internal transcribed spacers (ITS) for fungi and $18 \mathrm{~S}$ for other eukaryotes), play a major role in characterizing and deciphering the complex network of interactions occurring in the seagrass holobiont [78-80]. Even if this approach theoretically allows the precise identification of individual partners constituting a holobiont, and their functional potentials, there are several hurdles that yet need to be overcome. A major problem is the need of standardized methods during the whole experimental workflow, including: (i) sampling procedures, (ii) sample processing to obtain crude DNA extracts, (iii) amplification and sequencing steps and (iv) processing and analysis of raw data.

The sampling step is obviously strictly related to the aim of the study and to the specific questions the research team wants to answer. Therefore, sampling sites, sample collection methods and number of replicates must be correctly defined/chosen to reach a good level of statistical significance and detect the whole species diversity and abundance. Moreover, collecting the microbial biofilm from the seagrass tissue is not a standardized practice and it may influence the outcome of the study. For instance, in several studies samples were rinsed with sterile seawater $[28,35,39,106,178,183,186,192,200]$ while this step was not applied in others $[24,25,31,93,120]$. In some cases, the microbial biofilm was collected by washing seagrass tissue with a hand-made solution [24,25,31], with sonication [39], from frozen seagrass samples [39], or directly using the seagrass tissues in the DNA extraction process [89], and even, in several studies, the procedure is not described in details.

The process to obtain DNA preparations for amplification and massive sequencing, by using different methods and commercial kits, is another key step that may introduce biases in the workflow for the characterization of the holobiont. This has been demonstrated for 16S rRNA gene profiling of microbiome samples processed with different DNA extraction protocols [208], or for whole-genome sequencing of complete communities by employing extraction kits from different manufacturers. Major variations in the obtained results were found to be related to the different extraction and sequencing methods applied [209]. In fact, even if the rapid development of alternative chemistries and processing approaches significantly improves data quality, the use of different polymerases (characterized by different performances for high \%G + C DNA regions and different error rates) or the presence of differently abundant sequences from specific taxa in the sample, can introduce a certain degree of bias resulting in a poor-quality level of results. In these studies, the use of a cell spike-in control of known concentration during the nucleic acid extraction step has been suggested to alleviate such problems and would also allow a more accurate quantification of organisms based on a known input value [209]. Moreover, the use of PCRfree protocols (such as Kapa Hyper Prep PCR-free or TruSeq DNA PCR-free) is expected to reduce biases due to amplification and occurring in calculations of abundances. Regarding the instruments used for sequencing NGS libraries, with Roche's decision to discontinue their 454-sequencing platform (the first NGS commercial platforms on the market), the Ion Torrent Personal Genome Machine (PGM) and Illumina platforms are now the most used machines for studies characterizing the holobiont, with the prevalence of Illumina over PGM that has recently significantly increased [210]. This is largely due to the ability of the former platform to limit the number of sequencing errors, especially indels [211], even though Quail et al. [212] showed that the PGM platform showed better performances, but at the expense of a higher false positive rate. In fact, while the $16 \mathrm{~S}$ fragments commonly used by Illumina include the V3-V4 hypervariable regions, determined by a paired-end sequencing approach on amplicons of approximately $460 \mathrm{bp}$, the PGM instrument allows one to obtain single, long reads covering the entire V1-V9 region, theoretically allowing better discrimination of the taxa present in a given sample.

Several software are available to analyze NGS data derived from microbiome investigations, with MOTHUR [213] and Quantitative Insights Into Microbial Ecology (QIIME) [214] being probably the most popular. Indeed, even if the software selection depends largely on the level of taxonomic depth and complexity to be reached, a study concluded that QIIME 
and MOTHUR were the most complete pipelines, with several features and thoroughly documented [215]. Additionally, to consider here is that some studies highlight the fact that the best software performances are related also to the specific NGS technology used in the experiment. In fact, although QIIME 1 is no longer supported (since the end of 2017), and was replaced by QIIME 2, a recent study that analyzed a mock specimen (an artificial known bacterial community) suggested that the best results are obtained using QIIME1 when PGM data are used, while when using data from Illumina the VSEARCH strategy, which can be implemented in QIIME, gave superior results [216].

Concerning the analysis step, the choice of an appropriate resource for taxonomic classification to decipher sequence information is fundamental to answer specific questions that are at the basis of a given investigation. The importance of this step was recently highlighted by the observations that not all resources can be mapped to others without conflicts, and that there is a great deal of difference between taxonomies that arise mainly for the differences in their size and structure [217].

Indeed, while three of the databases widely used in microbiome studies, i.e., SILVA [218], RDP [219] and NCBI Taxonomy [220], cover the complete domain spectrum of Bacteria, Archaea and Eukarya, other such as Greengenes [221] are limited to specific domains (Bacteria and Archaea). In addition, the taxonomic granularity that characterizes these resources is also different, with only Greengenes and NCBI Taxonomy reaching the species level, while SILVA and RDP allow the identification at the genus level. When working with these different resources, one should take into consideration that the use of gene subregions to identify taxa, often does not allow the discrimination between closely related taxa, which could require the complete sequencing of the ribosomal gene [222]. Lastly, while updated versions of SILVA and NCBI Taxonomy are available, Greengenes and RDP have not been updated since 2013 and 2016, respectively. These are just some of the differences among these resources, which have to be taken into account to perform the best selection for answering the biological question at the base of a given experiment.

As a final remark regarding the use of massive $16 \mathrm{~S}$ rRNA sequencing for studying the seagrass holobiont, at the moment, the use of (i) commercial kits able to provide efficient DNA extractions characterized by a low level of contaminants, (ii) a sequencing platforms with low error rates in base calling, such as those of Illumina and (iii) a well-documented and widely used software as QIIME 2, could be proposed as a sort of "best practice" to investigate the microbiota of the seagrasses holobiont. Furthermore, sampling procedures should be described in details and already standardized/available methods should be preferred.

Beside these types of characterization, other omic-related techniques are gradually contributing to provide detailed data of the different constituents of the seagrass holobiont and their interactions. For example, a transcriptomic approach was applied to investigate the short-term responses in gene expression of seagrasses exposed to stress, as changing temperature [223] or light availability [224]. Metabolomic investigations demonstrated changes in nitrogen and sulfur metabolism, not detected by classical techniques [102]. The application of these and other novel approaches will contribute to a better and deeper understanding of the seagrasses holobiont, for instance by elucidating the gene expression pattern and the metabolic activities related to specific associations or environmental conditions.

\section{Mutual Influence Seagrass/Microbes: Implication and Insights for the Development of an Integrated Index}

Biological and ecological indicators represent useful tools for environmental monitoring, being crucial for the description and prediction of environmental changes [225]. The application of biological indicators in monitoring is recommended by the European Marine Strategy Framework Directive (2008/56/EC), which is based on an integrated "ecosystem" approach. In addition to the common ecological quality indicators (macrophytes, diatoms, macrobenthos and fish), changes in the microbial communities associated with seagrasses deserve to be taken into consideration as putative indicator for environmental quality 
assessment in marine ecosystems, due to their sensitivity and high turnover, and many efforts are made to develop environmental microbial indices [226]. Inspired by AZTI's marine biotic index (AMBI index; [227]) for the assessment of the benthic ecological quality, the micro-AMBI [228] is an index that examines the response of soft-bottom benthic microbial communities to natural and man-induced disturbances in coastal and estuarine sandy environments [229]. This index showed a significant correlation between the relative abundance of microbial taxa and the sediment quality index.

The epiphytic microbial communities associated with seagrasses are diverse may establish symbiotic relationships with the host and respond rapidly to environmental changes [24,33]. Thus, the structural and compositional variations of seagrass associatedmicrobiomes may be informative of the seagrass ecological status and a useful marker of specific stress that other seagrass health metrics fail to detect. For this reason, it is highly important to apply an integrated approach in the evaluation of the ecological status of seagrasses, that may be influenced and sequentially influence the associated microbial communities, or use different techniques to highlight the ongoing physiological processes $[24,25,31]$.

Studies on seaweeds, more advanced than those on seagrass and reviewed elsewhere [72-74], revealed that in addition to host species and local conditions [183,230,231], the host health condition plays a pivotal role in determining the seaweed holobiont composition [57,76,77]. Marzinelli et al. [76], on a continental scale study, found that healthy organisms have different microbial pattern, geographically determined; on the contrary, stressed plants exhibit similar microbial colonizers across sites. Longford et al. [57] showed that the microbial community associated to a host changes following a disturbance, and may recover to the prestress state after the end of the disturbance. This give evidence that interactions within microbiomes have important implications for host health and disease resilience. Minich et al. [77] found that the kelp and the associated community responded in a stress-specific way to the environmental changes (elevated temperature and $\mathrm{pCO}_{2}$ ), highlighting the interactions among the host and the associated microbiota.

The relationship between the health condition of seagrass meadows and microbiota composition are still incipient [55], but studies that related seagrass descriptors and the epiphytic microbial community variation proposed microbes as putative markers [22,24,25,31,32], as seagrass associated microbial communities were found to change even at the small spatial scale in different environments [24,25].

Variation of the microbial epiphytic communities associated with $H$. stipulacea was found along with seagrass morphological and biochemical markers (i.e., pigments and phenols content $[24,25])$; different microbial groups characterized healthy or stressed seagrass meadows [21,22,32,122] and freshwater plants meadows [232]. Earlier studies that focused on $P$. oceanica $[21,22,122]$ found the dominance of certain bacterial groups in a declining meadow, such as Pseudoalteromonas [122] and sulfate-reducing bacteria and the increase of sulfide [21]. Martin et al. [32] combined 16S rRNA gene sequencing of the seagrass root microbiome of Halophila ovalis with seagrass health metrics (biomass, productivity and sulfide concentration into seagrass tissue) and found that groups of putative methylotrophic bacteria, iron cycling bacteria and $\mathrm{N}_{2}$ fixing bacteria were associated with "healthy" seagrasses, while "stressed" seagrasses were dominated by putative sulfur-cycling bacteria, both sulfide-oxidizing and sulphate-reducing.

A detailed overview of the studies that suggest and/or support the use of microbes as ecological indicators is summarized in the following table (Table 1). 
Table 1. Detailed list of studies with insights and attempts of the application of microbes as environmental/seagrass ecological indicators.

\begin{tabular}{|c|c|c|c|c|c|c|}
\hline $\begin{array}{l}\text { Seagrass } \\
\text { Species }\end{array}$ & $\begin{array}{c}\text { Seagrass } \\
\text { Descriptors and } \\
\text { Environmental } \\
\text { Parameters }\end{array}$ & $\begin{array}{c}\text { Plant Part and/or } \\
\text { Environmental } \\
\text { Matrix }^{a}\end{array}$ & Study Area & $\begin{array}{c}\text { Methods and Target } \\
\text { Organisms (in } \\
\text { Brackets) }\end{array}$ & Main Results & References \\
\hline $\begin{array}{c}\text { Amphibolis } \\
\text { antarctica, } \\
\text { Halodule uninervis }\end{array}$ & $\begin{array}{l}\text { Phosphorus and } \\
\text { salinity gradients }\end{array}$ & Sediment & $\begin{array}{l}\text { Shark Bay, } \\
\text { WA, } \\
\text { Australia }\end{array}$ & $\begin{array}{l}\text { Amplicon sequencing of } \\
\text { 16S rRNA genes. } \\
\text { Hydrolytic enzymes } \\
\text { measurement with } \\
\text { standard colorimetric } \\
\text { methods ( } \beta \text {-glucosidase } \\
\text { assayed with } \\
\text { 4-nitrophenyl } \\
\text { 3-glucopyranoside, acid } \\
\text { phosphatase, and } \\
\text { alkaline phosphatase } \\
\text { assayed with } \\
\text { 4-nitrophenyl } \\
\text { phosphate disodium } \\
\text { hexahydrate) } \\
\text { (Bacteria) }\end{array}$ & $\begin{array}{l}\text { Adaptations } \\
\text { within the } \\
\text { microbial } \\
\text { community point } \\
\text { to potential } \\
\text { coevolution } \\
\text { between } \\
\text { seagrasses and } \\
\text { sediment } \\
\text { microorganisms } \\
\text { may help both } \\
\text { groups thrive in } \\
\text { the extreme } \\
\text { environment }\end{array}$ & $\begin{array}{c}\text { Fraser et al., } \\
2018 \\
{[190]}\end{array}$ \\
\hline $\begin{array}{l}\text { Cymodocea } \\
\text { serrulata, } \\
\text { Halodule uninervis, } \\
\text { Halophila ovalis }\end{array}$ & $\begin{array}{l}\text { Different light } \\
\text { treatments }\end{array}$ & Rhizosphere & $\begin{array}{c}\text { Useless Loop } \\
\text { in Shark Bay, } \\
\text { Western } \\
\text { Australia }\end{array}$ & $\begin{array}{c}\text { Amplicon sequencing of } \\
\text { the 16S rRNA genes } \\
\text { (Bacteria) }\end{array}$ & $\begin{array}{l}\text { The effect of light } \\
\text { reduction on root } \\
\text { exudation and the } \\
\text { consequent } \\
\text { reduction of } \\
\text { putative } \\
\text { beneficial } \\
\text { microorganisms }\end{array}$ & $\begin{array}{c}\text { Martin et al., } \\
2018 \\
{[29]}\end{array}$ \\
\hline Enhalus acroides & $\begin{array}{l}\mathrm{CO}_{2} \text {-vents } \\
\text { proximity }\end{array}$ & Phyllosphere & $\begin{array}{c}\text { Papua New } \\
\text { Guinea }\end{array}$ & $\begin{array}{l}\text { Quantitative technique } \\
\text { ARISA and Amplicon } \\
\text { sequencing of 16S rRNA } \\
\text { and 18S rRNA gene } \\
\text { (Bacteria, Eukaryotes) }\end{array}$ & $\begin{array}{c}\text { Bacterial } \\
\text { community } \\
\text { showed a } \\
\text { site-related } \\
\text { pattern at the } \\
\mathrm{CO}_{2} \text { vents with } \\
\text { an increase of } \\
\text { bacterial types } \\
\text { associated with } \\
\text { coral diseases }\end{array}$ & $\begin{array}{c}\text { Hassenrück } \\
\text { et al., } 2015 \\
\text { [23] }\end{array}$ \\
\hline Halophila ovalis & $\begin{array}{l}\text { Healthy vs. } \\
\text { stressed } \\
\text { meadows: } \\
\text { biomass, } \\
\text { productivity and } \\
\text { F-sulphide }\end{array}$ & Rhizosphere & $\begin{array}{l}\text { Multiple } \\
\text { locations } \\
\text { across } \\
\text { South-west } \\
\text { Western } \\
\text { Australia }\end{array}$ & $\begin{array}{c}\text { Amplicon sequencing of } \\
\text { the 16S rRNA } \\
\text { (Bacteria) }\end{array}$ & $\begin{array}{l}\text { Suggested the use } \\
\text { of the epiphytic } \\
\text { microbes to } \\
\text { detected clues of } \\
\text { stress that other } \\
\text { seagrass health } \\
\text { metrics failed to } \\
\text { detect }\end{array}$ & $\begin{array}{c}\text { Martin et al., } \\
2020 \\
{[32]}\end{array}$ \\
\hline $\begin{array}{l}\text { Halophila ovalis, } \\
\text { Zostera muelleri }\end{array}$ & $\begin{array}{l}\text { Radial oxygen } \\
\text { loss around root } \\
\text { tips }\end{array}$ & Rhizosphere & $\begin{array}{c}\text { Swan River } \\
\text { estuary, } \\
\text { Western } \\
\text { Australia }\end{array}$ & $\begin{array}{l}\text { Confocal fluorescence in } \\
\text { situ hybridization, } \\
\text { oxygen, sulphide } \\
\text { microsensor, Amplicon } \\
\text { sequencing of the } 16 S \\
\text { rRNA genes } \\
\text { (Bacteria) }\end{array}$ & $\begin{array}{c}\text { Roots leaking } \\
\text { oxygen had a } \\
\text { higher abundance } \\
\text { of sulphide- } \\
\text { oxidizing cable } \\
\text { bacteria }\end{array}$ & $\begin{array}{c}\text { Martin et al., } \\
2018 \\
{[26]}\end{array}$ \\
\hline $\begin{array}{l}\text { Halophila } \\
\text { stipulacea }\end{array}$ & $\begin{array}{c}\text { Morphometry, } \\
\text { total phenols, } \\
\text { photosynthetic } \\
\text { pigments. } \\
\text { Anthropogenic } \\
\text { pressure, } \\
\text { granulometry, } \\
\text { TOC\% }\end{array}$ & $\begin{array}{l}\text { Phyllosphere, } \\
\text { rhizosphere }\end{array}$ & $\begin{array}{c}\text { Gulf of } \\
\text { Aqaba, Israel }\end{array}$ & $\begin{array}{c}\text { Amplicon sequencing of } \\
\text { 16S rRNA genes } \\
\text { (Bacteria) }\end{array}$ & $\begin{array}{l}\text { Proposed } \\
\text { assessing the } \\
\text { ecological status } \\
\text { of seagrasses } \\
\text { using their } \\
\text { microbiota }\end{array}$ & $\begin{array}{c}\text { Mejia et al., } \\
2016 \\
{[24]}\end{array}$ \\
\hline
\end{tabular}


Table 1. Cont

\begin{tabular}{|c|c|c|c|c|c|c|}
\hline $\begin{array}{l}\text { Halophila } \\
\text { stipulacea }\end{array}$ & $\begin{array}{l}\text { Morphometry, } \\
\text { total phenols, } \\
\text { photosynthetic } \\
\text { pigments. } \\
\text { Depth gradient, } \\
\text { granulometry, } \\
\text { TOC\% }\end{array}$ & $\begin{array}{l}\text { Phyllosphere, } \\
\text { rhizosphere }\end{array}$ & $\begin{array}{c}\text { Gulf of } \\
\text { Aqaba, Israel }\end{array}$ & $\begin{array}{l}\text { Amplicon sequencing of } \\
\text { 16S rRNA genes } \\
\text { (Bacteria) }\end{array}$ & $\begin{array}{l}\text { High variability } \\
\text { was observed in } \\
\text { the epiphytic } \\
\text { microbiota along } \\
\text { a depth gradient }\end{array}$ & $\begin{array}{c}\text { Rotini et al., } \\
2017 \\
{[25]}\end{array}$ \\
\hline Posidonia oceanica & Mortality rate & $\begin{array}{l}\text { Phyllosphere, } \\
\text { rhizosphere }\end{array}$ & $\begin{array}{l}\text { Western } \\
\text { Mediter- } \\
\text { ranean } \\
\text { Sea }\end{array}$ & $\begin{array}{c}\text { 16S rRNA gene clone } \\
\text { library } \\
\text { (Bacteria) }\end{array}$ & $\begin{array}{l}\text { Pseudoalteromonas } \\
\text { was more } \\
\text { abundant in the } \\
\text { meadow with the } \\
\text { highest mortality } \\
\text { rate }\end{array}$ & $\begin{array}{l}\text { Marco-Noales } \\
\text { et al., 2006 } \\
\text { [22] }\end{array}$ \\
\hline Posidonia oceanica & Regression rate & Rhizosphere & $\begin{array}{c}\text { Balearic } \\
\text { Island, Spain }\end{array}$ & $\begin{array}{l}\text { 16S rRNA gene clone } \\
\text { library, DAPI, FISH } \\
\text { (Bacteria) }\end{array}$ & $\begin{array}{l}\text { Suggested a link } \\
\text { between the } \\
\text { documented } \\
\text { regression of the } \\
\text { meadow and the } \\
\text { decline of the } \\
\text { rhizosphere } \\
\text { microbial } \\
\text { community }\end{array}$ & $\begin{array}{l}\text { García- } \\
\text { Martinez et al., } \\
2008 \\
{[21]}\end{array}$ \\
\hline $\begin{array}{l}\text { Thalassia } \\
\text { hemprichii }\end{array}$ & $\begin{array}{l}\text { Three different } \\
\text { reef system } \\
\text { Ammonium, } \\
\text { nitrate, nitrite, } \\
\text { and phosphate in } \\
\text { seawater }\end{array}$ & $\begin{array}{l}\text { Phyllosphere, } \\
\text { rhizosphere, bulk } \\
\text { sediment }\end{array}$ & $\begin{array}{c}\text { Sanya Bay } \\
\text { and Yongxing } \\
\text { Island, South } \\
\text { China Sea }\end{array}$ & $\begin{array}{l}\text { DNA and cDNA qPCR } \\
\text { targeting } a m o A \text { genes } \\
\text { [ammonia } \\
\text { monooxygenase- } \\
\text { subunit] } \\
\text { (Bacteria) }\end{array}$ & $\begin{array}{l}\text { Significant } \\
\text { relationships } \\
\text { between the } \\
\text { abundance of } \\
\text { archaeal } \text { amo } A \\
\text { gene in } \\
\text { rhizosphere and } \\
\text { the ammonium } \\
\text { concentration in } \\
\text { sediments and } \\
\text { nitrogen content } \\
\text { in plant tissue }\end{array}$ & $\begin{array}{c}\text { Ling et al., } 2018 \\
\text { [180] }\end{array}$ \\
\hline $\begin{array}{l}\text { Thalassia } \\
\text { hemprichii }\end{array}$ & $\begin{array}{c}\text { Hsp60, Hsp70 } \\
\text { expression in } \\
\text { leaves, } \\
\text { morphometry in } \\
\text { different day time }\end{array}$ & $\begin{array}{l}\text { Phyllosphere, } \\
\text { rhizosphere }\end{array}$ & $\begin{array}{l}\text { Lagoon of } \\
\text { Magoodhoo } \\
\text { island, } \\
\text { Maldives }\end{array}$ & $\begin{array}{l}\text { Amplicon sequencing of } \\
\text { 16S rRNA gene } \\
\text { (Bacteria) }\end{array}$ & $\begin{array}{l}\text { Coupled daily } \\
\text { changes of } \\
\text { microbiome } \\
\text { composition and } \\
\text { HSP60 expression. } \\
\text { Microbiota } \\
\text { variation is an } \\
\text { early clue of } \\
\text { change of } \\
\text { seagrass } \\
\text { physiological } \\
\text { state }\end{array}$ & $\begin{array}{l}\text { Rotini et al., } \\
2020 \\
{[31]}\end{array}$ \\
\hline Vallisneria natans & $\begin{array}{c}\text { Heavy metals } \\
\text { exposure }\left(\mathrm{Cu}^{2+},\right. \\
\mathrm{Pb}^{2+}, \mathrm{Cd}^{2+} \text { and } \\
\text { mixture). } \\
\text { Plant growth, } \\
\text { water chemistry } \\
\text { and heavy metals } \\
\text { bioaccumulation }\end{array}$ & Phyllosphere & $\begin{array}{l}\text { Tiancun } \\
\text { Horticultural } \\
\text { Company, } \\
\text { Shanghai, } \\
\text { China }\end{array}$ & $\begin{array}{l}\text { High-throughput } \\
\text { amplicon sequencing of } \\
\text { the 16S rRNA gene } \\
\text { (Bacteria) }\end{array}$ & $\begin{array}{l}\text { Abundances and } \\
\text { structures of } \\
\text { biofilm } \\
\text { communities } \\
\text { changed in } \\
\text { response to heavy } \\
\text { metal stress } \\
\text { exposure }\end{array}$ & $\begin{array}{l}\text { Huang et al., } \\
\text { 2020 } \\
\text { [232] }\end{array}$ \\
\hline Zostera spp. & $\begin{array}{c}\text { Presence/absence } \\
\text { of seagrass, inside } \\
\text { vs. outside the } \\
\text { bay }\end{array}$ & Seawater column & $\begin{array}{l}\text { San Diego } \\
\text { Bay, USA }\end{array}$ & $\begin{array}{c}\text { Amplicon sequencing } \\
\text { 16S rRNA gene } \\
\text { sequencing, flow } \\
\text { cytometry } \\
\text { (Bacteria) }\end{array}$ & $\begin{array}{l}\text { The current flow } \\
\text { rather than the } \\
\text { seagrass presence } \\
\text { shapes the } \\
\text { seawater column } \\
\text { microbial } \\
\text { community }\end{array}$ & $\begin{array}{l}\text { Webb et al., } \\
2019 \\
{[176]}\end{array}$ \\
\hline
\end{tabular}


Table 1. Cont.

\begin{tabular}{|c|c|c|c|c|c|c|}
\hline $\begin{array}{l}\text { Zostera japonica, } \\
\text { Zostera marina }\end{array}$ & $\begin{array}{c}\text { Mixed meadows, } \\
\text { different sites }\end{array}$ & $\begin{array}{l}\text { Phyllosphere, } \\
\text { Rhizosphere, } \\
\text { seawater }\end{array}$ & $\begin{array}{l}\text { Netarts Bay, } \\
\text { OR, United } \\
\text { States }\end{array}$ & $\begin{array}{l}\text { Amplicon sequencing of } \\
\text { the } 16 \mathrm{~S} \text { rRNA genes and } \\
\text { metatranscriptomics } \\
\text { (Bacteria) }\end{array}$ & $\begin{array}{l}\text { Microbe-plant } \\
\text { mutualisms } \\
\text { support the } \\
\text { health and } \\
\text { growth of aquatic } \\
\text { plants }\end{array}$ & $\begin{array}{c}\text { Crump et al., } \\
2018 \\
{[27]}\end{array}$ \\
\hline $\begin{array}{l}\text { Zostera japonica, } \\
\text { Zostera marina }\end{array}$ & $\begin{array}{l}\text { Vegetated vs. } \\
\text { degraded areas }\end{array}$ & Rhizosphere & $\begin{array}{l}\text { Swan Lake, } \\
\text { China }\end{array}$ & $\begin{array}{l}\text { High-throughput } \\
\text { amplicon sequencing of } \\
\text { the } 16 \mathrm{~S} \text { rRNA gene } \\
\text { (Bacteria) }\end{array}$ & $\begin{array}{c}\text { Different } \\
\text { microbiota found } \\
\text { in vegetated and } \\
\text { degraded areas. } \\
\text { Vibrionaceae could } \\
\text { lead to seagrass } \\
\text { degradation }\end{array}$ & $\begin{array}{c}\text { Sun et al., } 2020 \\
\text { [191] }\end{array}$ \\
\hline Zostera marina & $\begin{array}{l}\text { Leaf area. } \\
\text { Depth, } \\
\text { lagoon/open } \\
\text { coast }\end{array}$ & Phyllosphere & $\begin{array}{l}\text { In- and } \\
\text { out-side } \\
\text { lagoons on } \\
\text { the German } \\
\text { Baltic Sea } \\
\text { coast }\end{array}$ & $\begin{array}{c}\text { Amplicon sequencing of } \\
\text { 16S and 18S rRNA } \\
\text { genes } \\
\text { (Bacteria, Eukaryotes) }\end{array}$ & $\begin{array}{l}\text { Correlation } \\
\text { between } \\
\text { eukaryotic } \\
\text { diversity and } \\
\text { prokaryotic } \\
\text { microbiome }\end{array}$ & $\begin{array}{c}\text { Bengtsson et al., } \\
2017 \\
{[178]}\end{array}$ \\
\hline Zostera marina & $\begin{array}{l}\text { Inner/edge } \\
\text { plants position in } \\
\text { the meadow }\end{array}$ & $\begin{array}{l}\text { Phyllosphere, } \\
\text { rhizosphere, } \\
\text { sediment }\end{array}$ & $\begin{array}{l}\text { Bodega Bay, } \\
\text { USA }\end{array}$ & $\begin{array}{c}\text { Amplicon sequencing of } \\
\text { 16S rRNA genes } \\
\text { (Bacteria) }\end{array}$ & $\begin{array}{c}\text { Seagrass } \\
\text { microbiota do not } \\
\text { feel the edge } \\
\text { effect }\end{array}$ & $\begin{array}{l}\text { Ettinger et al., } \\
\qquad 2017 \\
{[96]}\end{array}$ \\
\hline Zostera marina & $\begin{array}{l}\text { Presence/absence } \\
\text { of seagrass, } \\
\text { distance from the } \\
\text { shore and along } \\
\text { the reefs }\end{array}$ & Seawater column & $\begin{array}{l}\text { Spermonde } \\
\text { Archipelago, } \\
\text { Indonesia }\end{array}$ & $\begin{array}{c}\text { Amplicon sequencing } \\
\text { 16S rRNA gene } \\
\text { sequencing and } \\
\text { Enterococcus assays. } \\
\text { (Bacteria) }\end{array}$ & $\begin{array}{l}\text { Seagrass presence } \\
\text { caused } 50 \% \\
\text { reduction in the } \\
\text { relative } \\
\text { abundance of } \\
\text { potential bacterial } \\
\text { pathogens }\end{array}$ & $\begin{array}{l}\text { Lamb et al., } \\
2017 \\
{[193]}\end{array}$ \\
\hline Zostera muelleri & $\begin{array}{c}\text { Radial } \mathrm{O}_{2} \text { loss } \\
\text { and } \mathrm{H}_{2} \mathrm{~S} \\
\text { concentration at } \\
\text { the basal leaf } \\
\text { meristem } \\
\text { (Microsensor) }\end{array}$ & Rhizosphere & $\begin{array}{l}\text { Narra-Been } \\
\text { Lagoon, } \\
\text { NSW, } \\
\text { Australia }\end{array}$ & $\begin{array}{c}\text { Amplicon sequencing of } \\
\text { the 16S rRNA genes } \\
\text { (Bacteria) }\end{array}$ & $\begin{array}{l}\text { Seagrass- } \\
\text { mediated } \\
\text { alterations of } \\
\text { rhizosphere } \\
\text { geochemistry } \\
\text { result in shifts of } \\
\text { the rhizosphere } \\
\text { microbial } \\
\text { community } \\
\text { composition }\end{array}$ & $\begin{array}{c}\text { Brodersen et al., } \\
2018 \\
{[89]}\end{array}$ \\
\hline Zostera muelleri & Plant sections & $\begin{array}{l}\text { Upper leaf, lower } \\
\text { leaf, sheath, roots } \\
\text { and rhizomes }\end{array}$ & $\begin{array}{l}\text { New South } \\
\text { Wales, } \\
\text { Australia }\end{array}$ & $\begin{array}{c}\text { Amplicon sequencing of } \\
\text { 16S and 18S rRNA gene, } \\
\text { ITS2 (5.8S) rRNA gene } \\
\text { (Bacteria, Eukaryotes, } \\
\text { Fungi) }\end{array}$ & $\begin{array}{c}\text { Identified a "core" } \\
\text { microbiome likely } \\
\text { play key roles in } \\
\text { seagrass } \\
\text { physiology, } \\
\text { ecology and } \\
\text { biogeochemistry }\end{array}$ & $\begin{array}{c}\text { Hurtado- } \\
\text { McCormick } \\
\text { et al., } 2019 \\
\text { [93] }\end{array}$ \\
\hline
\end{tabular}

${ }^{a}=$ phyllosphere and rhizosphere are the terms indicated by the authors; in this paper we preferred to use the terms aboveground and belowground, respectively.

The ecological and health condition of seagrass host seems to be an important shaping factor of the associated microbial communities and of the overall seagrass holobiont. Furthermore, the mutual influence between seagrass and environmental microbial communities, although is still little explored, suggesting that the seagrass associated-microbes could be a tool to monitor the environmental changes and the seagrass ecological status and, potentially, their manipulation could be useful to preserve and/or restore seagrass ecosystems. This might allow us to prevent the ongoing decline of seagrass meadows and, potentially, the invasiveness of exotic species, and to control the spread of pathogens both from humans and from marine organisms.

Here we list some of the main aspects that should be considered and further investigated in order to define early warning indicators of seagrass health and to develop, hopefully, in the near future, an integrated microbial community-based index. 
(a) Occurrence and relative abundance of specific bacterial groups (taxonomy) and/or genes or metabolic pathways (functionality) can be putative markers, particularly those involved in important biogeochemical transformations within the nitrogen, sulfur and carbon cycles and thus able to affect the ecology / physiology of the seagrass host.

(b) Abundance pattern and contributions of rare vs. abundant components of the holobiont microbial partner into the integrity of the seagrass host health status and the related ecological processes. For example, the rare microbial components can have greater sensitivity to both natural- and human-induced disturbances and/or exert significant impacts on seagrass ecosystem health, plasticity or resilience. Similarly, the core microbiome and the changing components of the seagrass associated microbial communities can give a different contribution to the functional structure of the microbial assemblages and thus to the ecological status of the seagrass holobiont. However, instead of a universally important seagrass-microbial core, a local or species-specific microbial core might be useful to identify.

(c) Differences and roles of the microbiomes associated with the different anatomic plant compartments, which can reflect and be related to the characteristics of the environmental matrices (sediment vs. seawater). For example, the belowground compartment seems to be an extremely conservative microenvironment for seagrass associated microbial community, showing good sensitivity to the seagrass physiological condition and responding to the environmental conditions; the aboveground microbial community, instead, showed higher variability and seemed more easily influenced by the seawater conditions. Thus, the belowground microbial community may be suitable to monitor the seagrass ecological status while the aboveground microbial community may track the environmental changes, making seagrass leaves a good reference surface to monitor environmental variations or disturbances.

(d) Plant surface colonization patterns/pathways and ecological interactions occurring within the seagrass epiphytic microbial community can be complex and have important implications for the holobiont health and disease (e.g., symbiosis, competition, predation, antifouling and antimicrobial activities); thus, they deserve attention and further investigation to give an insight of the host-microbial functional relationships.

\section{Conclusions}

The possible methodological approaches based on the use of microbes (or microbiomes) as bioindicators in the marine environment monitoring are several, however standardized methods or at least a proposal of "best practices" should be defined (including the sample collection and processing and the raw data analyses) for seagrass holobiont investigations (see Section 3). Due to genomic and metagenomic advances, the seagrass associated microbial communities are increasingly known and it is now possible to study their role and interactions with the host plant. There is still much to do in this field, but already now the microbiome represents a challenge for ecotoxicology, to exploit the potential development of ecological/ecotoxicological indices. Field and mesocosm experiments by using an integrated approach that combine microbiome analysis and seagrass descriptors are recommended to investigate the response of the holobiont to physical-chemical variations and environmental disturbances.

Author Contributions: Conceptualization, C.C., A.R., L.M. (Luciana Migliore); writing-original draft preparation, C.C., A.R., G.W., L.M. (Luciana Migliore), M.M.D., L.M. (Loredana Manfra); WritingReview and editing, all authors. All authors have read and agreed to the published version of the manuscript.

Funding: C.C. was funded by a three-year Ph.D. grant from the Rome University of Tor Vergata (XXXIV cycle), Doctorate in Evolutionary Biology and Ecology.

Acknowledgments: We would like to thank Sarit Ashckenazi-Polivoda for her precious help in designing the graphical abstract. 
Conflicts of Interest: The authors declare no conflict of interest. The funder had no role in the design of the study; in the collection, analyses, or interpretation of data; in the writing of the manuscript, or in the decision to publish the results.

\section{References}

1. den Hartog, C.; Kuo, J. Taxonomy and Biogeography of Seagrasses. In Seagrasses: Biology, Ecology and Conservation; Larkum, A.W.D., Orth, R.J., Duarte, C., Eds.; Springer: Dordrecht, The Netherlands, 2006; pp. 1-23. ISBN 140202942X.

2. Duarte, C.M. Seagrass depth limits. Aquat. Bot. 1991, 40, 363-377. [CrossRef]

3. Hemminga, M.A.; Duarte, C.M. Taxonomy and distribution. In Seagrass Ecology; Hemminga, M.A., Duarte, C.M., Eds.; Cambridge University Press: Cambridge, UK, 2000; pp. 1-26. ISBN 0-521-66184-6.

4. Wright, J.P.; Jones, C.G. The concept of organisms as ecosystem engineers ten years on: Progress, limitations, and challenges. Bioscience 2006, 56, 203-209. [CrossRef]

5. Nordlund, L.M.; Koch, E.W.; Barbier, E.B.; Creed, J.C. Seagrass Ecosystem Services and Their Variability across Genera and Geographical Regions. PLoS ONE 2016, 11, e0163091. [CrossRef]

6. $\quad$ Beck, M.W.; Heck, K.L.; Able, K.W.; Childers, D.L.; Eggleston, D.B.; Gillanders, B.M.; Halpern, B.; Hays, C.G.; Hoshino, K.; Minello, T.J.; et al. The identification, conservation, and management of estuarine and marine nurseries for fish and invertebrates. Bioscience 2001, 51, 633-641. [CrossRef]

7. Jiang, Z.; Cui, L.; Liu, S.; Zhao, C.; Wu, Y.; Chen, Q.; Yu, S.; Li, J.; He, J.; Fang, Y.; et al. Historical changes in seagrass beds in a rapidly urbanizing area of Guangdong Province: Implications for conservation and management. Glob. Ecol. Conserv. 2020, 22, e01035. [CrossRef]

8. Jeyabaskaran, R.; Jayasankar, J.; Ambrose, T.V.; Valsalan, K.C.V.; Divya, N.D.; Raji, N.; Vysakhan, P.; John, S.; Prema, D.; Kaladharan, P.; et al. Conservation of seagrass beds with special reference to associated species and fishery resources. J. Mar. Biol. Assoc. India 2018, 60, 62-70. [CrossRef]

9. Duarte, C.M.; Marbà, N.; Gacia, E.; Fourqurean, J.W.; Beggins, J.; Barrón, C.; Apostolaki, E.T. Seagrass community metabolism: Assessing the carbon sink capacity of seagrass meadows. Glob. Biogeochem. Cycles 2010, 24, 1-8. [CrossRef]

10. Duarte, C.M.; Middelburg, J.J.; Caraco, N. Major role of marine vegetation on the oceanic carbon cycle. Biogeosciences 2005, 1, 173-180. [CrossRef]

11. Orth, R.J.; Carruthers, T.J.B.; Dennison, W.C.; Duarte, C.M.; Fourqurean, J.W.; Kenneth, L.H.J.; Hughes, A.R.; Kendrick, G.A.; Kenworthy, W.J.; Olyarnik, S.; et al. A Global Crisis for Seagrass Ecosystems. Bioscience 2006, 56, 987-996. [CrossRef]

12. Waycott, M.; Duarte, C.M.; Carruthers, T.J.B.; Orth, R.J.; Dennison, W.C.; Olyarnik, S.; Calladine, A.; Fourqurean, J.W.; Heck, K.L.; Hughes, A.R.; et al. Accelerating loss of seagrasses across the globe threatens coastal ecosystems. Proc. Natl. Acad. Sci. USA 2009, 106, 12377-12381. [CrossRef]

13. Short, F.T.; Neckles, H.A. The effects of global climate change on seagrasses. Aquat. Bot. 1999, 63, 169-196. [CrossRef]

14. Duarte, B.; Martins, I.; Rosa, R.; Matos, A.R.; Roleda, M.Y.; Reusch, T.B.H.; Engelen, A.H.; Serrão, E.A.; Pearson, G.A.; Marques, J.C.; et al. Climate Change Impacts on Seagrass Meadows and Macroalgal Forests: An Integrative Perspective on Acclimation and Adaptation Potential. Front. Mar. Sci. 2018, 5. [CrossRef]

15. de los Santos, C.B.; Krause-Jensen, D.; Alcoverro, T.; Marbà, N.; Duarte, C.M.; Van Katwijk, M.M.; Pérez, M.; Romero, J.; Sánchez-lizaso, J.L.; Trayter, G.M.; et al. Recent trend reversal for declining European seagrass meadows. Nat. Commun. 2019, 10, 1-8. [CrossRef] [PubMed]

16. Pergent, G.; Pergent-Martini, C.; Boudouresque, C.F. Utilisation de l'herbier a Posidonia oceanica comme indicateur biologique de la qualité du milieu littoral en méditerranée: État des connaissances. Mésogée 1995, 54, 3-27.

17. Martínez-Crego, B.; Vergés, A.; Alcoverro, T.; Romero, J. Selection of multiple seagrass indicators for environmental biomonitoring. Mar. Ecol. Prog. Ser. 2008, 361, 93-109. [CrossRef]

18. Roca, G.; Alcoverro, T.; Krause-Jensen, D.; Balsby, T.J.S.; Van Katwijk, M.M.; Marbà, N.; Santos, R.; Arthur, R.; Mascaró, O.; Fernández-Torquemada, Y.; et al. Response of seagrass indicators to shifts in environmental stressors: A global review and management synthesis. Ecol. Indic. 2016, 63, 310-323. [CrossRef]

19. Rotini, A.; Anello, L.; Di Bernardo, M.; Giallongo, A.; Valiante, L.; Migliore, L. Comparative analysis of bed density, total phenol content and protein expression pattern in Posidonia oceanica (L.) Delile. Open J. Ecol. 2013, 3, 438-444. [CrossRef]

20. Migliore, L.; Rotini, A.; Randazzo, D.; Albanese, N.N.; Giallongo, A. Phenols content and 2-D electrophoresis protein pattern: A promising tool to monitor Posidonia meadows health state. BMC Ecol. 2007, 7, 1-8. [CrossRef] [PubMed]

21. García-Martínez, M.; López-López, A.; Calleja, M.L.; Marbà, N.; Duarte, C.M. Bacterial community dynamics in a seagrass (Posidonia oceanica) meadow sediment. Estuaries Coasts 2008, 32, 276-286. [CrossRef]

22. Marco-Noales, E.; Ordax, M.; Armando, D.; Lopez, M.M.; Saavedra, M.J.; Martinez-Murcia, A.; Garcias, N.; Marbá, N.; Duarte, C.M. Microbiota associated with P. oceanica in Western Mediterranean Sea. Mod. Multidiscip. Appl. Microbiol. 2006, 342-350. [CrossRef]

23. Hassenrück, C.; Hofmann, L.C.; Bischof, K.; Ramette, A. Seagrass biofilm communities at a naturally $\mathrm{CO}_{2}$-rich vent. Environ. Microbiol. Rep. 2015, 7, 516-525. [CrossRef] [PubMed] 
24. Mejia, A.Y.; Rotini, A.; Lacasella, F.; Bookman, R.; Thaller, M.C.; Shem-tov, R.; Winters, G.; Migliore, L. Assessing the ecological status of seagrasses using morphology, biochemical descriptors and microbial community analyses. A study in Halophila stipulacea (Forsk.) Aschers meadows in the. Ecol. Indic. 2016, 60, 1150-1163. [CrossRef]

25. Rotini, A.; Mejia, A.Y.; Costa, R.; Migliore, L.; Winters, G. Ecophysiological Plasticity and Bacteriome Shift in the Seagrass Halophila stipulacea along a Depth Gradient in the Northern Red Sea. Front. Plant Sci. 2017, 7, 1-12. [CrossRef] [PubMed]

26. Martin, B.C.; Bougoure, J.; Ryan, M.H.; Bennett, W.W.; Colmer, T.D.; Joyce, N.K.; Olsen, Y.S.; Kendrick, G.A. Oxygen loss from seagrass roots coincides with colonisation of sulphide-oxidising cable bacteria and reduces sulphide stress. ISME J. 2018, 13, 707-719. [CrossRef]

27. Crump, B.C.; Wojahn, J.M.; Tomas, F.; Mueller, R.S. Metatranscriptomics and amplicon sequencing reveal mutualisms in seagrass microbiomes. Front. Microbiol. 2018, 9, 1-14. [CrossRef] [PubMed]

28. Cúcio, C.; Overmars, L.; Engelen, A.H.; Muyzer, G. Metagenomic Analysis Shows the Presence of Bacteria Related to Free-Living Forms of Sulfur-Oxidizing Chemolithoautotrophic Symbionts in the Rhizosphere of the Seagrass Zostera marina. Front. Mar. Sci. 2018, 5, 1-15. [CrossRef]

29. Martin, B.C.; Gleeson, D.; Statton, J.; Siebers, A.R.; Grierson, P.; Ryan, M.H.; Kendrick, G.A. Low light availability alters root exudation and reduces putative beneficial microorganisms in seagrass roots. Front. Microbiol. 2018, 8, 1-16. [CrossRef]

30. Tarquinio, F.; Jeremy, B.; Koenders, A.; Hyndes, G.A. Microorganisms facilitate uptake of dissolved organic nitrogen by seagrass leaves. ISME J. 2018, 12, 2796-2800. [CrossRef] [PubMed]

31. Rotini, A.; Conte, C.; Seveso, D.; Montano, S.; Galli, P.; Vai, M.; Migliore, L.; Mejia, A. Daily variation of the associated microbial community and the Hsp60 expression in the Maldivian seagrass Thalassia hemprichii. J. Sea Res. 2020, 156, 101835. [CrossRef]

32. Martin, B.C.; Sanchez Alcaron, M.; Gleeson, D.; Middleton, J.A. Root microbiomes as indicators of seagrass health. FEMS Microbiol. Ecol. 2020, 96, fiz201. [CrossRef] [PubMed]

33. Zilber-Rosenberg, I.; Rosenberg, E. Role of microorganisms in the evolution of animals and plants: The hologenome theory of evolution. FEMS Microbiol. Rev. 2008, 32, 723-735. [CrossRef]

34. Valdez, S.R.; Zhang, Y.S.; van der Heide, T.; Vanderklift, M.A.; Tarquinio, F.; Orth, R.J.; Silliman, B.R. Positive Ecological Interactions and the Success of Seagrass Restoration. Front. Mar. Sci. 2020, 7, 1-11. [CrossRef]

35. Uku, J.; Björk, M.; Bergman, B.; Díez, B. Characterization and comparison of prokaryotic epiphytes associated with three East African seagrasses. J. Phycol. 2007, 43, 768-779. [CrossRef]

36. Crump, B.C.; Koch, E.W. Attached Bacterial Populations Shared by Four Species of Aquatic Angiosperms. Appl. Environ. Microbiol. 2008, 74, 5948-5957. [CrossRef] [PubMed]

37. Wahbeh, M.I.; Mahasneh, A.M. Heterotrophic Bacteria Attached To Leaves, Rhizomes And Roots of Three Seagrass Species From Aqaba (Jordan). Aquat. Bot. 1984, 20, 87-96. [CrossRef]

38. Cúcio, C.; Engelen, A.H.; Costa, R.; Muyzer, G.; Costa, R. Rhizosphere Microbiomes of European Seagrasses Are Selected by the Plant, But Are Not Species Specific. Front. Microbiol. 2016, 7. [CrossRef]

39. Ugarelli, K.; Laas, P.; Stingl, U. The Microbial Communities of Leaves and Roots Associated with Turtle Grass (Thalassia testudinum) and Manatee Grass (Syringodium filliforme) are Distinct from Seawater and Sediment Communities, but Are Similar between Species and Sampling Sites. Microorganisms 2018, 7, 4. [CrossRef]

40. Trevathan-Tackett, S.M.; Sherman, C.D.H.; Huggett, M.J.; Campbell, A.H.; Laverock, B.; Hurtado-McCormick, V.; Seymour, J.R.; Firl, A.; Messer, L.F.; Ainsworth, T.D.; et al. A horizon scan of priorities for coastal marine microbiome research. Nat. Ecol. Evol. 2019, 3, 1509-1520. [CrossRef] [PubMed]

41. Wilkins, L.G.E.; Leray, M.; O’Dea, A.; Yuen, B.; Peixoto, R.S.; Pereira, T.J.; Bik, H.M.; Coil, D.A.; Duffy, J.E.; Herre, E.A.; et al. Host-associated microbiomes drive structure and function of marine ecosystems. PLoS Biol. 2019, 17, 1-15. [CrossRef] [PubMed]

42. Dittami, S.; Arboleda, E.; Auguet, J.-C.; Bigalke, A.; Briand, E.; Cardenas, P.; Cardini, U.; Decelle, J.; Engelen, A.; Eveillard, D.; et al. A community perspective on the concept of marine holobionts: Current status, challenges, and future directions. PeerJ 2019, 1-22. [CrossRef]

43. Margulis, L.; Fester, R. Symbiosis as a Source of Evolutionary Innovation: Special Ion and Morphogenesis; MIT Press: Cambridge, UK, 1991; ISBN 0-262-13269-9.

44. O'Malley, M.A. Endosymbiosis and its implications for evolutionary theory. Proc. Natl. Acad. Sci. USA 2015, 112, 10270-10277. [CrossRef] [PubMed]

45. Gray, M.W. Lynn Margulis and the endosymbiont hypothesis: 50 years later. Mol. Biol. Cell 2017, 28, 1285-1287. [CrossRef] [PubMed]

46. Baedke, J.; Fábregas-Tejeda, A.; Nieves Delgado, A. The holobiont concept before Margulis. J. Exp. Zool. Part B Mol. Dev. Evol. 2020, 334, 149-155. [CrossRef] [PubMed]

47. Rosenberg, E.; Zilber-Rosenberg, I. Microbes Drive Evolution of Animals and Plants: The Hologenome Concept. MBio 2016, 3 , 193-224. [CrossRef] [PubMed]

48. Roughgarden, J.; Gilbert, S.F.; Rosenberg, E.; Zilber-Rosenberg, I.; Lloyd, E.A. Holobionts as Units of Selection and a Model of Their Population Dynamics and Evolution. Biol. Theory 2018, 13, 44-65. [CrossRef]

49. Bordenstein, S.R.; Theis, K.R. Host biology in light of the microbiome: Ten principles of holobionts and hologenomes. PLoS Biol. 2015, 13, 1-23. [CrossRef] [PubMed] 
50. de Bustos Muñoz, M.T.; Guirao, J.L.G.; Vera López, J.A.; Campuzano, A.V. The hologenome concept of evolution after 10 years. Qual. Theory Dyn. Syst. 2018, 14, 265-280. [CrossRef]

51. Theis, K.R.; Dheilly, N.M.; Klassen, J.L.; Brucker, R.M.; Baines, J.F.; Lloyd, E.A.; Sapp, J.; Vandenkoornhuyse, P.; Zilber-Rosenberg, I.; Rosenberg, E.; et al. Getting the Hologenome Concept Right: An Eco-Evolutionary Framework for Hosts and Their Microbiomes. Msystems 2016, 1, e00028. [CrossRef] [PubMed]

52. Bang, C.; Dagan, T.; Deines, P.; Dubilier, N.; Duschl, W.J.; Fraune, S.; Hentschel, U.; Hirt, H.; Hülter, N.; Lachnit, T.; et al. Metaorganisms in extreme environments: Do microbes play a role in organismal adaptation? Zoology 2018, 127, 1-19. [CrossRef] [PubMed]

53. Simon, J.C.; Marchesi, J.R.; Mougel, C.; Selosse, M.A. Host-microbiota interactions: From holobiont theory to analysis. Microbiome 2019, 7, 1-5. [CrossRef]

54. Vandenkoornhuyse, P.; Quaiser, A.; Duhamel, M.; Le Van, A.; Dufresne, A. The importance of the microbiome of the plant holobiont. New Phytol. 2015, 206, 1196-1206. [CrossRef]

55. Sullivan, B.K.; Trevathan-Tackett, S.M.; Neuhauser, S.; Govers, L.L. Review: Host-pathogen dynamics of seagrass diseases under future global change. Mar. Pollut. Bull. 2018, 134, 75-88. [CrossRef]

56. Pitlik, S.D.; Koren, O. How holobionts get sick-toward a unifying scheme of disease. Microbiome 2017, 5. [CrossRef] [PubMed]

57. Longford, S.R.; Campbell, A.H.; Nielsen, S.; Case, R.J.; Kjelleberg, S.; Steinberg, P.D. Interactions within the microbiome alter microbial interactions with host chemical defences and affect disease in a marine holobiont. Sci. Rep. 2019, 9, 1363. [CrossRef] [PubMed]

58. Egan, S.; Gardiner, M. Microbial dysbiosis: Rethinking disease in marine ecosystems. Front. Microbiol. 2016, 7, 1-8. [CrossRef] [PubMed]

59. Ursell, L.K.; Metcalf, J.M.; Parfrey, L.W.; Knight, R. Defining the Human Microbiome. Nat. Rev. Microbiol. 2012, 70. [CrossRef] [PubMed]

60. Wang, B.; Yao, M.; Lv, L.; Ling, Z.; Li, L. The Human Microbiota in Health and Disease. Engineering 2017, 3, 71-82. [CrossRef]

61. Lerner, A.; Neidhöfer, S.; Matthias, T. The Gut Microbiome Feelings of the Brain: A Perspective for Non-Microbiologists. Microorganisms 2017, 5, 66. [CrossRef]

62. Carthey, A.J.R.; Blumstein, D.T.; Gallagher, R.V.; Tetu, S.G.; Gillings, M.R. Conserving the holobiont. Funct. Ecol. 2019, 34, 764-776. [CrossRef]

63. Thompson, J.R.; Rivera, H.E.; Closek, C.J.; Medina, M. Microbes in the coral holobiont: Partners through evolution, development, and ecological interactions. Front. Cell. Infect. Microbiol. 2015, 4, 1-20. [CrossRef] [PubMed]

64. Reshef, L.; Koren, O.; Loya, Y.; Zilber-Rosenberg, I.; Rosenberg, E. The Coral Probiotic Hypothesis. Environ. Microbiol. 2006, 8, 2068-2073. [CrossRef] [PubMed]

65. Pita, L.; Rix, L.; Slaby, B.M.; Franke, A.; Hentschel, U. The sponge holobiont in a changing ocean: From microbes to ecosystems. Microbiome 2018, 6, 46. [CrossRef] [PubMed]

66. Vollmer, S.V.; Baker, A.C.; Coffroth, M.-A.; Harvell, C.D.; Medina, M. Understanding the coral holobiont through science and scuba. Smithson. Contrib. Mar. Sci. 2013, 39, 173-186.

67. Hassani, M.A.; Durán, P.; Hacquard, S. Microbial interactions within the plant holobiont. Encycl. Syst. Biol. 2018, 6, 902. [CrossRef] [PubMed]

68. Sánchez-Cañizares, C.; Jorrín, B.; Poole, P.S.; Tkacz, A. Understanding the holobiont: The interdependence of plants and their microbiome. Curr. Opin. Microbiol. 2017, 38, 188-196. [CrossRef] [PubMed]

69. Lemanceau, P.; Barret, M.; Mazurier, S.; Mondy, S.; Pivato, B.; Fort, T.; Vacher, C. Plant Communication with Associated Microbiota in the Spermosphere, Rhizosphere and Phyllosphere. In How Plants Communicate with Their Biotic Environment; Becard, G., Ed.; Academic Press: Cambridge, MA, USA, 2017; Volume 82, pp. 101-133. ISBN 9780128014318.

70. Long, S.R. Rhizobium-legume nodulation: Life together in the underground. Cell 1989, 56, 203-214. [CrossRef]

71. Masson-Boivin, C.; Sachs, J.L. Symbiotic nitrogen fixation by rhizobia-The roots of a success story. Curr. Opin. Plant Biol. 2018, 44, 7-15. [CrossRef]

72. van der Loos, L.M.; Eriksson, B.K.; Falcão Salles, J. The Macroalgal Holobiont in a Changing Sea. Trends Microbiol. 2019, 27, 635-650. [CrossRef] [PubMed]

73. Singh, R.P.; Reddy, C.R.K. Seaweed-microbial interactions: Key functions of seaweed-associated bacteria. FEMS Microbiol. Ecol. 2014, 88, 213-230. [CrossRef]

74. Egan, S.; Harder, T.; Burke, C.; Steinberg, P.; Kjelleberg, S.; Thomas, T. The seaweed holobiont: Understanding seaweed-bacteria interactions. FEMS Microbiol. Rev. 2013, 37, 462-476. [CrossRef]

75. Thurber, R.V.; Willner-Hall, D.; Rodriguez-Mueller, B.; Desnues, C.; Edwards, R.A.; Angly, F.; Dinsdale, E.; Kelly, L.; Rohwer, F. Metagenomic analysis of stressed coral holobionts. Environ. Microbiol. 2009, 11, 2148-2163. [CrossRef] [PubMed]

76. Marzinelli, E.M.; Campbell, A.H.; Valdes, Z.E.; Vergés, A.; Nielsen, S.; Wernberg, T.; de Bettignies, T.; Bennett, S.; Caporaso, J.G.; Thomas, T.; et al. Continental-scale variation in seaweed host-associated bacterial communities is a function of host condition, not geography. Environ. Microbiol. 2015. [CrossRef] [PubMed]

77. Minich, J.J.; Morris, M.M.; Brown, M.; Doane, M.; Edwards, M.S.; Michael, T.P.; Dinsdale, E.A. Elevated temperature drives kelp microbiome dysbiosis, while elevated carbon dioxide induces water microbiome disruption. PLoS ONE 2018, 13, e0192772. [CrossRef] [PubMed] 
78. Ugarelli, K.; Chakrabarti, S.; Laas, P.; Stingl, U. The Seagrass Holobiont and Its Microbiome. Microorganisms 2017, 5, 81. [CrossRef] [PubMed]

79. Tarquinio, F.; Hyndes, G.A.; Laverock, B.; Koenders, A.; Säwström, C. The seagrass holobiont: Understanding seagrass-bacteria interactions and their role in seagrass ecosystem functioning. FEMS Microbiol. Lett. 2019, 366, fnz057. [CrossRef]

80. Seymour, J.R.; Laverock, B.; Nielsen, D.A.; Macreadie, P.I. The Microbiology of Seagrass. In Seagrasses of Australia; Larkum, A.W.D., Kendrick, G.A., Ralph, P.J., Eds.; Springer International Publishing: Berlin/Heidelberg, Germany, 2018 ; pp. 343-392. ISBN 978-3-319-71352-6. [CrossRef]

81. Garcias-Bonet, N.; Arrieta, J.M.; de Santana, C.N.; Duarte, C.M.; Marbà, N. Endophytic bacterial community of a Mediterranean marine angiosperm (Posidonia oceanica). Front. Microbiol. 2012, 3, 1-16. [CrossRef]

82. Croft, M.T.; Lawrence, A.D.; Raux-Deery, E.; Warren, M.J.; Smith, A.G. Algae acquire vitamin B12 through a symbiotic relationship with bacteria. Nature 2005, 438, 90-93. [CrossRef]

83. Touchette, B.W.; Burkholder, J.A.M. Review of nitrogen and phosphorus metabolism in seagrasses. J. Exp. Mar. Bio. Ecol. 2000, 250, 133-167. [CrossRef]

84. Brodersen, K.E.; Koren, K.; Moßhammer, M.; Ralph, P.J.; Ku, M.; Santner, J. Seagrass-Mediated Phosphorus and Iron Solubilization in Tropical Sediments. Environ. Sci. Technol. 2017, 51, 14155-14163. [CrossRef] [PubMed]

85. Holmer, M.; Andersen, F.O.; Nielsen, S.L.; Boschker, H.T.S. The importance of mineralization based on sulfate reduction for nutrient regeneration in tropical seagrass sediments. Aquat. Bot. 2001, 71, 1-17. [CrossRef]

86. Welsh, D.T. Nitrogen fixation in seagrass meadows: Regulation, plant-bacteria interactions and significance to primary productivity. Ecol. Lett. 2000, 3, 58-71. [CrossRef]

87. Zimmerman, R.; Smith, R.; Alberte, R. Is growth of eelgrass nitrogen limited? A numerical simulation of the effects of light and nitrogen on the growth dynamics of Zostera marina. Mar. Ecol. Prog. Ser. 1987, 41, 167-176. [CrossRef]

88. Celdrán, D.; Espinosa, E.; Sánchez-Amat, A.; Marín, A. Effects of epibiotic bacteria on leaf growth and epiphytes of the seagrass Posidonia oceanica. Mar. Ecol. Prog. Ser. 2012, 456, 21-27. [CrossRef]

89. Brodersen, K.E.; Siboni, N.; Nielsen, D.A.; Pernice, M.; Ralph, P.J.; Seymour, J.; Kuhl, M. Seagrass rhizosphere microenvironment alters plant-associated microbial community composition. Environ. Microbiol. 2018, 20, 2854-2864. [CrossRef] [PubMed]

90. Brodersen, K.E.; Michael, K.; Nielsen, D.A.; Pedersen, O.; Larkum, A.W.D. Rhizome, Root/Sediment Interactions, Aerenchyma and Internal Pressure Changes in Seagrasses. In Seagrasses of Australia; Larkum, A.W.D., Kendrick, G.A., Ralph, P.J., Eds.; Springer International Publishing: Berlin/Heidelberg, Germany, 2018; pp. 393-418. ISBN 9783319713540.

91. Nielsen, L.B.; Finster, K.; Welsh, D.T.; Donelly, A.; Herbert, R.A.; De Wit, R.; Lomstein, B.A. Sulphate reduction and nitrogen fixation rates associated with roots, rhizomes and sediments from Zostera noltii and Spartina maritima meadows. Environ. Microbiol. 2001, 3, 63-71. [CrossRef]

92. Lehnen, N.; Marchant, H.K.; Schwedt, A.; Milucka, J.; Lott, C.; Weber, M.; Dekaezemacker, J.; Seah, B.K.B.; Hach, P.F.; Mohr, W.; et al. High rates of microbial dinitrogen fixation and sulfate reduction associated with the Mediterranean seagrass Posidonia oceanica. Syst. Appl. Microbiol. 2016, 39, 476-483. [CrossRef] [PubMed]

93. Hurtado-McCormick, V.; Kahlke, T.; Petrou, K.; Jeffries, T.; Ralph, P.J.; Seymour, J.R.; Hill, R.T. Regional and Microenvironmental Scale Characterization of the Zostera muelleri Seagrass Microbiome. Front. Microbiol. 2019, 10, 1-22. [CrossRef] [PubMed]

94. Carbonero, F.; Oakley, B.B.; Purdy, K.J. Metabolic Flexibility as a Major Predictor of Spatial Distribution in Microbial Communities. PLoS ONE 2014, 9, e85105. [CrossRef] [PubMed]

95. Sun, F.; Zhang, X.; Zhang, Q.; Liu, F.; Zhang, J.; Gong, J. Seagrass (Zostera marina) colonization promotes the accumulation of diazotrophic bacteria and alters the relative abundances of specific bacterial lineages involved in benthic carbon and sulfur cycling. Appl. Environ. Microbiol. 2015, 81, 6901-6914. [CrossRef]

96. Ettinger, C.L.; Voerman, S.E.; Lang, J.M.; Stachowicz, J.J.; Eisen, J.A. Microbial communities in sediment from Zostera marina patches, but not the Z. marina leaf or root microbiomes, vary in relation to distance from patch edge. PeerJ 2017, 2017, 1-25. [CrossRef]

97. Ettinger, C.L.; Williams, S.L.; Abbott, J.M.; Stachowicz, J.J.; Eisen, J.A. Microbiome succession during ammonification in eelgrass bed sediments. PeerJ 2017, 2017, 1-17. [CrossRef]

98. Garcias-Bonet, N.; Arrieta, J.M.; Duarte, C.M.; Marbà, N. Nitrogen-fixing bacteria in Mediterranean seagrass (Posidonia oceanica) roots. Aquat. Bot. 2016, 131, 57-60. [CrossRef]

99. Jensen, S.I.; Kühl, M.; Priemé, A. Different bacterial communities associated with the roots and bulk sediment of the seagrass Zostera marina. FEMS Microbiol. Ecol. 2007, 62. [CrossRef]

100. Kristensen, E.; Holmer, M. Decomposition of plant materials in marine sediment exposed to different electron acceptors $\left(\mathrm{O}_{2}\right.$, $\mathrm{NO}_{3}$, and $\mathrm{SO}_{4}{ }^{2-}$ ), with emphasis on substrate origin, degradation kinetics, and the role of bioturbation. Geochim. Cosmochim. Acta 2001, 65, 419-433. [CrossRef]

101. Apostolaki, E.T.; Holmer, M.; Santinelli, V.; Karakassis, I. Species-specific response to sulfide intrusion in native and exotic Mediterranean seagrasses under stress. Mar. Environ. Res. 2018, 134, 85-95. [CrossRef] [PubMed]

102. Hasler-Sheetal, H.; Fragner, L.; Holmer, M.; Weckwerth, W. Diurnal effects of anoxia on the metabolome of the seagrass Zostera marina. Metabolomics 2015, 11, 1208-1218. [CrossRef]

103. Brodersen, K.E.; Lichtenberg, M.; Paz, L.C.; Kühl, M. Epiphyte-cover on seagrass (Zostera marina L.) leaves impedes plant performance and radial $\mathrm{O}_{2}$ loss from the below-ground tissue. Front. Mar. Sci. 2015, 2, 1-11. [CrossRef] 
104. Van Der Heide, T.; Govers, L.L.; De Fouw, J.; Olff, H.; Van Der Geest, M.; Van Katwijk, M.M.; Piersma, T.; Van De Koppel, J.; Silliman, B.R.; Smolders, A.J.P.; et al. A three-stage symbiosis forms the foundation of seagrass ecosystems. Science 2012, 336, 1432-1434. [CrossRef]

105. Pereg, L.L.; Lipkin, Y.; Sar, N. Different niches of the Halophila stipulacea seagrass bed harbor distinct populations of nitrogen fixing bacteria. Mar. Biol. 1994, 119, 327-333. [CrossRef]

106. Garcias-Bonet, N.; Fusi, M.; Ali, M.; Shaw, D.R.; Saikaly, P.E.; Daffonchio, D.; Duarte, C.M. High denitrification and anaerobic ammonium oxidation contributes to net nitrogen loss in a seagrass ecosystem in the central Red Sea. Biogeosciences 2018, 15, 7333-7346. [CrossRef]

107. Hamisi, M.; Díez, B.; Lyimo, T.; Ininbergs, K.; Bergman, B. Epiphytic cyanobacteria of the seagrass Cymodocea rotundata: Diversity, diel nifH expression and nitrogenase activity. Environ. Microbiol. 2013, 5. [CrossRef]

108. Mayavu, P.; Sugesh, S.; Ravindran, V.J. Antibacterial activity of seagrass species against biofilm forming bacteria. Res. J. Microbiol. 2009, 4, 314-319. [CrossRef]

109. Howayada, H.A.E.-H.; Eman, R.H.; Abeer, N.S. Molecular Identification, Antimicrobial and Antioxidant Activities of the Tropical Seagrass Halophila stipulacea Grown in El-Bardawil Lake. Aust. J. Basic Appl. Sci. 2012, 6, 474-481.

110. Babuselvam, M.; Farook, K.A.; Abideen, S.; Peer Mohamed, M.; Uthiraselvam, M. Screening of Antibacterial Activity of Mangrove Leaf. Int. J. Appl. Microbiol. Sci. 2012, 13, 20-25.

111. Satheesh, S.; Ba-Akdah, M.A.; Al-Sofyani, A.A. Natural antifouling compound production by microbes associated with marine macroorganisms-A review. Electron. J. Biotechnol. 2016, 21, 26-35. [CrossRef]

112. Wu, H.; Chen, W.; Wang, G.; Dai, S.; Zhou, D.; Zhao, H.; Guo, Y.; Ouyang, Y.; Li, X. Culture-dependent diversity of Actinobacteria associated with seagrass (Thalassia hemprichii). Afr. J. Microbiol. Res. 2012, 6, 87-94. [CrossRef]

113. Armstrong, E.; Yan, L.; Boyd, K.G.; Wright, P.C.; Burgess, J.G. The symbiotic role of marine microbes on living surfaces. Hydrobiologia 2001, 461, 37-40. [CrossRef]

114. Rao, D.; Webb, J.S.; Kjelleberg, S. Competitive Interactions in Mixed-Species Biofilms Containing the Marine Bacterium Pseudoalteromonas tunicata Dhana. Appl. Environ. Microbiol. 2005, 71, 1-8. [CrossRef]

115. Ravikumar, S.; Gnanadesigan, M.; Saravanan, A.; Monisha, N.; Brindha, V.; Muthumari, S. Antagonistic properties of seagrass associated Streptomyces sp. RAUACT-1: A source for anthraquinone rich compound. Asian Pac. J. Trop. Med. 2012, 5, 887-890. [CrossRef]

116. Ravikumar, S.; Thajuddin, N.; Suganthi, P.; Jacob Lnbaneson, S.; Vinodkumar, T. Bioactive potential of seagrass bacteria against human bacterial pathogens. J. Environ. Biol. 2010, 31, 387-389. [PubMed]

117. Marhaeni, B.; Radjasa, O.K.; Bengen, D.G.; Kaswadji, R.F. Screening of bacterial symbionts of seagrass Enhalus sp. against biofilm-forming bacteria. J. Coast. Dev. 2010, 13, 126-132.

118. Marhaeni, B.; Radjasa, O.K.; Sabdono, A.; Sudoyo, H. Antifouling Activity of Bacterial Symbionts of Seagrasses against Marine Biofilm-Forming Bacteria. J. Environ. Prot. (Irvine Calif.) 2011, 2, 1245-1249. [CrossRef]

119. Inaba, N.; Trainer, V.L.; Onishi, Y.; Ishii, K.I.; Wyllie-Echeverria, S.; Imai, I. Algicidal and growth-inhibiting bacteria associated with seagrass and macroalgae beds in Puget Sound, WA, USA. Harmful Algae 2017, 62, 136-147. [CrossRef] [PubMed]

120. Fahimipour, A.K.; Kardish, M.R.; Lang, J.M.; Green, J.L.; Eisen, J.A.; Stachowicz, J.J. Globalscale structure of the eelgrass microbiome. Appl. Environ. Microbiol. 2017, 83. [CrossRef] [PubMed]

121. Kohn, T.; Rast, P.; Kallscheuer, N.; Wiegand, S.; Boedeker, C.; Jetten, M.S.M.; Jeske, O.; Vollmers, J.; Kaster, A.K.; Rohde, M.; et al. The Microbiome of Posidonia oceanica Seagrass Leaves Can Be Dominated by Planctomycetes. Front. Microbiol. 2020, $11,1458$. [CrossRef] [PubMed]

122. García-Martínez, M.; Kuo, J.; Kilminster, K.; Walker, D.; Rosselló-Mora, R.; Duarte, C.M. Microbial colonization in the seagrass Posidonia spp. roots. Mar. Biol. Res. 2005, 1, 388-395. [CrossRef]

123. Fraser, M.W.; Statton, J.; Hovey, R.K.; Laverock, B.; Kendrick, G.A. Seagrass derived organic matter influences biogeochemistry, microbial communities, and seedling biomass partitioning in seagrass sediments. Plant Soil 2016, 400, 133-146. [CrossRef]

124. Fourqurean, J.W.; Duarte, C.M.; Kennedy, H.; Marbà, N.; Holmer, M.; Mateo, M.A.; Apostolaki, E.T.; Kendrick, G.A.; KrauseJensen, D.; McGlathery, K.J.; et al. Seagrass ecosystems as a globally significant carbon stock. Nat. Geosci. 2012, 5, 505-509. [CrossRef]

125. Liu, S.; Jiang, Z.; Zhou, C.; Wu, Y.; Arbi, I.; Zhang, J.; Huang, X.; Trevathan-Tacket, S.M. Leaching of dissolved organic matter from seagrass leaf litter and its biogeochemical implications. Acta Oceanol. Sin. 2018, 37, 84-90. [CrossRef]

126. Macreadie, P.I.; Atwood, T.B.; Seymour, J.R.; Fontes, M.L.S.; Sanderman, J.; Nielsen, D.A.; Connolly, R.M. Vulnerability of seagrass blue carbon to microbial attack following exposure to warming and oxygen. Sci. Total Environ. 2019, 686, 264-275. [CrossRef]

127. Dang, H. Grand Challenges in Microbe-Driven Marine Carbon Cycling Research. Front. Microbiol. 2020, 11. [CrossRef] [PubMed]

128. Bouillon, S.; Boschker, H.T.S.; Brussel, V.U. Bacterial carbon sources in coastal sediments: A cross-system analysis based on stable isotope data of biomarkers. Biogeosciences 2006, 3, 175-185. [CrossRef]

129. Liu, S.; Jiang, Z.; Wu, Y.; Zhang, J.; Arbi, I.; Ye, F.; Huang, X.; Macreadie, P.I. Effects of nutrient load on microbial activities within a seagrass-dominated ecosystem: Implications of changes in seagrass blue carbon. Mar. Pollut. Bull. 2017, 117, 214-221. [CrossRef] [PubMed]

130. Trevathan-Tackett, S.M.; Jeffries, T.C.; Macreadie, P.I.; Manojlovic, B.; Ralph, P. Long-term decomposition captures key steps in microbial breakdown of seagrass litter. Sci. Total Environ. 2020, 705, 135806. [CrossRef] [PubMed] 
131. Trevathan-tackett, S.M.; Seymour, J.R.; Nielsen, D.A.; Macreadie, P.I.; Jeffries, T.C.; Sanderman, J.; Baldock, J.; Howes, J.M.; Steven, A.D.L.; Ralph, P.J. Sediment anoxia limits microbial-driven seagrass carbon remineralization under warming conditions. FEMS Microbiol. Ecol. 2017, 93, 1-15. [CrossRef]

132. Pedersen, М.Ø.; Serrano, O.; Mateo, M.Á.; Holmer, M. Temperature effects on decomposition of a Posidonia oceanica mat. Aquat. Microb. Ecol. 2011, 65, 169-182. [CrossRef]

133. Trevathan-Tackett, S.M.; Macreadie, P.I.; Sanderman, J.; Baldock, J.; Howes, J.M.; Ralph, P.J. A Global Assessment of the Chemical Recalcitrance of Seagrass Tissues: Implications for Long-Term Carbon Sequestration. Front. Plant Sci. 2017, 8. [CrossRef] [PubMed]

134. Macreadie, P.I.; Hardy, S.S.S. Response of seagrass "Blue Carbon" stocks to increased water temperatures. Diversity 2018, 10, 115. [CrossRef]

135. Winters, G.; Beer, S.; Willette, D.A.; Viana, I.G.; Chiquillo, K.L. The Tropical Seagrass Halophila stipulacea: Reviewing What We Know from Its Native and Invasive Habitats, Alongside Identifying Knowledge Gaps. Front. Mar. Sci. 2020, 7. [CrossRef]

136. Gambi, M.C.; Barbieri, F.; Bianchi, C.N. New record of the alien seagrass Halophila stipulacea (Hydrocharitaceae) in the western Mediterranean: A further clue to changing Mediterranean Sea biogeography. Mar. Biodivers. Rec. 2009, 2. [CrossRef]

137. Sghaier, Y.R.; Zakhama-Sraieb, R.; Mouelhi, S.; Vazquez, M.; Valle, C.; Ramos-Espla, A.A.; Astier, J.M.; Verlaque, M.; CharfiCheikhrouha, F. Review of alien marine macrophytes in Tunisia. Mediterr. Mar. Sci. 2016, 17, 109-123. [CrossRef]

138. Sghaier, Y.R.; Zakhama-Sraieb, R.; Benamer, I.; Charfi-Cheikhrouha, F. Occurrence of the seagrass Halophila stipulacea (Hydrocharitaceae) in the southern Mediterranean Sea. Bot. Mar. 2011, 54, 575-582. [CrossRef]

139. Willette, D.A.; Ambrose, R.F. Effects of the invasive seagrass Halophila stipulacea on the native seagrass, Syringodium filiforme, and associated fish and epibiota communities in the Eastern Caribbean. Aquat. Bot. 2012, 103, 74-82. [CrossRef]

140. Vera, B.; Collado-Vides, L.; Moreno, C.; van Tussenbroek, B.I. Halophila stipulacea (Hydrocharitaceae): A Recent Introduction to the Continental Waters of Venezuela. Caribb. J. Sci. 2014, 48, 66-70. [CrossRef]

141. Scheibling, R.E.; Patriquin, D.G.; Filbee-Dexter, K. Distribution and abundance of the invasive seagrass Halophila stipulacea and associated benthic macrofauna in Carriacou, Grenadines, Eastern Caribbean. Aquat. Bot. 2018, 144, 1-8. [CrossRef]

142. Willette, D.A.; Chalifour, J.; Debrot, A.O.D.; Engel, M.S.; Miller, J.; Oxenford, H.A.; Short, F.T.; Steiner, S.C.C.; Védie, F. Continued expansion of the trans-Atlantic invasive marine angiosperm Halophila stipulacea in the eastern Caribbean. Aquat. Bot. 2014, 112, 98-102. [CrossRef]

143. van Tussenbroek, B.I.; Govers, L.L.; van der Heide, T.; van Katwijk, M.M.; Bouma, T.J.; Leuven, R.S.E.W. Non-native seagrass Halophila stipulacea forms dense mats under eutrophic conditions in the Caribbean. J. Sea Res. 2016, 115, 1-5. [CrossRef]

144. Smulders, F.O.H.; Vonk, J.A.; Engel, M.S.; Christianen, M.J.A. Expansion and fragment settlement of the non-native seagrass Halophila stipulacea in a Caribbean bay. Mar. Biol. Res. ISSN 2017, 13, 967-974. [CrossRef]

145. Streftaris, N.; Zenetos, A. Alien marine species in the Mediterranean-The 100 "worst invasives" and their impact. Mediterr. Mar. Sci. 2006, 7, 87-118. [CrossRef]

146. Bianchi, C.N.; Morri, C. Global sea warming and "tropicalization" of the Mediterranean Sea: Biogeographic and ecological aspects. Biogeogr. J. Integr. Biogeogr. 2003, 24. [CrossRef]

147. Sghier, Y.R.; Zakhama-Sraieb, R.; Charfi-Cheikhrouha, F. Effects of the invasive seagrass Halophila stipulacea on the native seagrass Cymodocea Nodosa. In Proceedings of the 5th Mediterranean Symposium on Marine Vegetation, Portorož, Slovenia, 27-28 October 2014; pp. 27-28.

148. Sharon, Y.; Silva, J.; Santos, R.; Runcie, J.W.; Chernihovsky, M.; Beer, S. Photosynthetic responses of Halophila stipulacea to a light gradient. II. Acclimations following transplantation. Aquat. Biol. 2009, 7, 153-157. [CrossRef]

149. Sharon, Y.; Beer, S. Diurnal movements of chloroplasts in Halophila stipulacea and their effect on PAM fluorometric measurements of photosynthetic rates. Aquat. Bot. 2008, 88, 273-276. [CrossRef]

150. Oscar, M.A.; Barak, S.; Winters, G. The Tropical Invasive Seagrass, Halophila stipulacea, Has a Superior Ability to Tolerate Dynamic Changes in Salinity Levels Compared to Its Freshwater Relative, Vallisneria americana. Front. Plant Sci. 2018, 9, 1-19. [CrossRef] [PubMed]

151. Alexandre, A.; Luis, J.; Georgiou, D.; Alexandre, A.; Luis, J.; Santos, R. Temperature is not a limiting factor for the expansion of Halophila stipulacea throughout the whole Mediterranean Sea. Mar. Ecol. Prog. Ser. 2016, 544, 159-167. [CrossRef]

152. Azcárate-García, T.; Beca-Carretero, P.; Villamayor, B.; Stengel, D.B.; Winters, G. Responses of the seagrass Halophila stipulacea to depth and spatial gradients in its native region (Red Sea): Morphology, in situ growth and biomass production. Aquat. Bot. 2020, 165, 103252. [CrossRef]

153. Beca-Carretero, P.; Rotini, A.; Mejia, A.; Migliore, L.; Vizzini, S.; Winters, G. Halophila stipulacea descriptors in the native area (Red Sea): A baseline for future comparisons with native and non-native populations. Mar. Environ. Res. 2019, 153, 104828. [CrossRef] [PubMed]

154. Procaccini, G.; Acunto, S.; Famà, P.; Maltagliati, F. Structural, morphological and genetic variability in Halophila stipulacea (Hydrocharitaceae) populations in the western Mediterranean. Mar. Biol. 1999, 135, 181-189. [CrossRef]

155. Nguyen, H.M.; Yadav, N.S.; Barak, S.; Lima, F.P.; Sapir, Y.; Winters, G. Responses of Invasive and Native Populations of the Seagrass Halophila stipulacea to Simulated Climate Change. Front. Mar. Sci. 2020, 6, 1-16. [CrossRef]

156. Sharon, Y.; Levitan, O.; Spungin, D.; Berman-Frank, I.; Beer, S. Photoacclimation of the seagrass Halophila stipulacea to the dim irradiance at its 48-m depth limit. Limnol. Oceanogr. 2011, 56, 357-362. [CrossRef] 
157. Schwarz, A.M.; Hellblom, F. The photosynthetic light response of Halophila stipulacea growing along a depth gradient in the Gulf of Aqaba, the Red Sea. Aquat. Bot. 2002, 74, 263-272. [CrossRef]

158. Manh Nguyen, H.; Savva, I.; Kleitou, P.; Kletou, D.; Lima, F.P.; Sapir, Y.; Winters, G. Seasonal dynamics of native and invasive Halophila stipulacea populations-A case study from the northern Gulf of Aqaba and the eastern Mediterranean Sea. Aquat. Bot. 2020, 162, 103205. [CrossRef]

159. Hulings, N.C. The Ecology, Biometry and Biomass of the Seagrass Halophila stipulacea Along the Jordanian Coast of the Gulf of Aqaba. Bot. Mar. 1979, 22, 425-430. [CrossRef]

160. Lipkin, Y. Quantitative Aspects of Seagrass Communities, Particularly of Those Dominated by Halophila Stipulacea, in Sinai (Northern Red Sea). Aquat. Bot. 1979, 7, 119-128. [CrossRef]

161. Weidner, S.; Arnold, W.; Pühler, A. Diversity of uncultured microorganisms associated with the seagrass Halophila stipulacea estimated by restriction fragment length polymorphism analysis of PCR-amplified 16s rRNA genes. Appl. Environ. Microbiol. 1996, 62, 766-771. [CrossRef] [PubMed]

162. Weidner, S.; Arnold, W.; Stackebrandt, E.; Pühler, A. Phylogenetic analysis of bacterial communities associated with leaves of the seagrass Halophila stipulacea by a culture-independent small-subunit rRNA gene approach. Microb. Ecol. 2000, 39, 22-31. [CrossRef]

163. Dang, H.; Li, T.; Chen, M.; Huang, G. Cross-ocean distribution of Rhodobacterales bacteria as primary surface colonizers in temperate coastal marine waters. Appl. Environ. Microbiol. 2008, 74, 52-60. [CrossRef] [PubMed]

164. Elifantz, H.; Horn, G.; Ayon, M.; Cohen, Y.; Minz, D. Rhodobacteraceae are the key members of the microbial community of the initial biofilm formed in Eastern Mediterranean coastal seawater. FEMS Microbiol. Ecol. 2013, 85, 348-357. [CrossRef]

165. Buchan, A.; González, J.M.; Moran, M.A. Overview of the marine Roseobacter lineage. Appl. Environ. Microbiol. 2005, 71, 5665-5677. [CrossRef]

166. Campbell, A.M.; Fleisher, J.; Sinigalliano, C.; White, J.R.; Lopez, J.V. Dynamics of marine bacterial community diversity of the coastal waters of the reefs, inlets, and wastewater outfalls of southeast Florida. Microbiol. Open. 2015, 4, 390-408. [CrossRef] [PubMed]

167. Lemanceau, P.; Blouin, M.; Muller, D.; Moënne-Loccoz, Y. Let the Core Microbiota Be Functional. Trends Plant Sci. 2017, 22, 583-595. [CrossRef]

168. Garrity, G.M.; Bell, J.A.; Lilburn, T. Pseudomonadaceae. In Bergey's Manual of Systematics of Archaea and Bacteria; John Wiley \& Sons, Inc.: Hoboken, NJ, USA, 2015; ISBN 9781118960608.

169. Bitam, F.; Ciavatta, M.L.; Carbone, M.; Manzo, E.; Mollo, E.; Gavagnin, M. Chemical analysis of fl avonoid constituents of the seagrass Halophila stipulacea: First finding of malonylated derivatives in marine phanerogams. Biochem. Syst. Ecol. 2010, 38, 686-690. [CrossRef]

170. Zidorn, C. Secondary metabolites of seagrasses (Alismatales and Potamogetonales; Alismatidae): Chemical diversity, bioactivity, and ecological function. Phytochemistry 2016, 124, 5-28. [CrossRef] [PubMed]

171. Defranoux, F.; Mollo, E. Molecular Interactions as Drivers of Changes in Marine Ecosystems. In Co-Evolution of Secondary Metabolites; Mérillon, J.-M., Ramawat, K.G., Eds.; Springer Nature Switzerland AG: Cham, Switzerland, 2020; pp. 121-133. ISBN 9783319768878.

172. Mierziak, J.; Kostyn, K.; Kulma, A. Flavonoids as important molecules of plant interactions with the environment. Molecules 2014, 19, 16240-16265. [CrossRef] [PubMed]

173. Mannino, A.M.; Micheli, C. Ecological function of phenolic compounds from mediterranean fucoid algae and seagrasses: An overview on the genus Cystoseira sensu lato and Posidonia oceanica (L.) Delile. J. Mar. Sci. Eng. 2020, 8, 19. [CrossRef]

174. Gordon-Bradley, N.; Lymperopoulou, D.S.; Williams, H.N. Differences in bacterial community structure on Hydrilla verticillata and Vallisneria Americana in a freshwater spring. Microbes Environ. 2014, 29, 67-73. [CrossRef] [PubMed]

175. Garcias-Bonet, N.; Eguíluz, V.; Díaz-Rúa, R.; Duarte, C. Host-association as major driver of microbiome structure and composition in Red Sea seagrass ecosystems. Environ. Microbiol. 2020, 22. [CrossRef]

176. Webb, S.J.; Rabsatt, T.; Erazo, N.; Bowman, J.S. Impacts of Zostera eelgrasses on microbial community structure in San Diego coastal waters. Elem. Sci. Anthr. 2019, 7. [CrossRef]

177. Jiang, Y.; Ling, J.; Dong, J.; Chen, B.; Zhang, Y.; Zhang, Y.; Wang, Y. Illumina-based analysis the microbial diversity associated with Thalassia hemprichii in Xincun Bay, South China Sea. Ecotoxicology 2015, 24, 1548-1556. [CrossRef]

178. Bengtsson, M.M.; Bühler, A.; Brauer, A.; Dahlke, S.; Schubert, H. Eelgrass Leaf Surface Microbiomes Are Locally Variable and Highly Correlated with Epibiotic Eukaryotes. Front. Microbiol. 2017, 8. [CrossRef]

179. Conte, C.; Rotini, A.; Winters, G.; Vasquez, M.I.; Piazza, G.; Kletou, D.; Migliore, L. Elective affinities or random choice within the seagrass holobiont? The case of the native Posidonia oceanica (L.) Delile and the invasive Halophila stipulacea (Forssk.) Asch. from the same site (Limassol, Cyprus). Aquat. Bot.. under review.

180. Ling, J.; Lin, X.; Zhang, Y.; Zhou, W.; Yang, Q.; Lin, L.; Zeng, S.; Zhang, Y.; Wang, C.; Ahmad, M.; et al. Community composition and transcriptional activity of ammonia-oxidizing prokaryotes of seagrass Thalassia hemprichii in coral reef ecosystems. Front. Microbiol. 2018, 9, 1-13. [CrossRef] [PubMed]

181. Mansson, M.; Gram, L.; Larsen, T.O. Production of bioactive secondary metabolites by marine Vibrionaceae. Mar. Drugs 2011, 9 , 1440-1468. [CrossRef] [PubMed] 
182. Ismail, A.; Ktari, L.; Ahmed, M.; Bolhuis, H.; Bouhaouala-Zahar, B.; Stal, L.J.; Boudabbous, A.; El Bour, M. Heterotrophic bacteria associated with the green alga Ulva rigida: Identification and antimicrobial potential. J. Appl. Phycol. 2018, 30, $2883-2899$. [CrossRef]

183. Campbell, A.H.; Marzinelli, E.M.; Gelber, J.; Steinberg, P.D. Spatial variability of microbial assemblages associated with a dominant habitat-forming seaweed. Front. Microbiol. 2015, 6, 1-10. [CrossRef] [PubMed]

184. Burke, C.; Steinberg, P.; Rusch, D.; Kjelleberg, S.; Thomas, T. Bacterial community assembly based on functional genes rather than species. Proc. Natl. Acad. Sci. USA 2011, 108, 14288-14293. [CrossRef]

185. Mishra, A.K.; Mohanraju, R. Epiphytic Bacterial Communities in Seagrass Meadows of Oligotrophic Waters of Andaman Sea. Open Access Libr. J. 2018, 5. [CrossRef]

186. Marzinelli, E.M.; Qiu, Z.; Dafforn, K.A.; Johnston, E.L.; Steinberg, P.D.; Mayer-Pinto, M. Coastal urbanisation affects microbial communities on a dominant marine holobiont. NPJ Biofilms Microbiomes 2018, 4. [CrossRef] [PubMed]

187. Devereux, R.; Yates, D.F.; Aukamp, J.; Quarles, R.L.; Jordan, S.J.; Stanley, R.S.; Eldridge, P.M. Interactions of Thalassia testudinum and sediment biogeochemistry in Santa Rosa sound, NW Florida. Mar. Biol. Res. 2011, 7, 317-331. [CrossRef]

188. Bourque, A.S.; Vega-Thurber, R.; Fourqurean, J.W. Microbial community structure and dynamics in restored subtropical seagrass sediments. Aquat. Microb. Ecol. 2015, 74, 43-57. [CrossRef]

189. Donnelly, A.P.; Herbert, R.A. Bacterial interactions in the rhizosphere of seagrass communities in shallow coastal lagoons. J. Appl. Microbiol. 1998, 85, 151S-160S. [CrossRef]

190. Fraser, M.W.; Gleeson, D.B.; Grierson, P.F.; Laverock, B.; Kendrick, G.A. Metagenomic Evidence of Microbial Community Responsiveness to Phosphorus and Salinity Gradients in Seagrass Sediments. Front. Microbiol. 2018, 9, 1-11. [CrossRef] [PubMed]

191. Sun, Y.; Song, Z.; Zhang, H.; Liu, P.; Hu, X. Seagrass vegetation affect the vertical organization of microbial communities in sediment. Mar. Environ. Res. 2020, 162, 105174. [CrossRef] [PubMed]

192. Gribben, P.E.; Nielsen, S.; Seymour, J.R.; Bradley, D.J.; West, M.N.; Thomas, T. Microbial communities in marine sediments modify success of an invasive macrophyte. Sci. Rep. 2017, 7, 9845. [CrossRef]

193. Lamb, J.B.; Van De Water, J.A.J.M.; Bourne, D.G.; Altier, C.; Hein, M.Y.; Fiorenza, E.A.; Abu, N.; Jompa, J.; Harvell, C.D. Seagrass ecosystems reduce exposure to bacterial pathogens of humans, fishes, and invertebrates. Science 2017, 355, 731-733. [CrossRef] [PubMed]

194. Roth-Schulze, A.J.; Zozaya-Valdés, E.; Steinberg, P.D.; Thomas, T. Partitioning of functional and taxonomic diversity in surfaceassociated microbial communities. Environ. Microbiol. 2016, 18, 4391-4402. [CrossRef] [PubMed]

195. Sale, P.F. Coexistence of coral reef fishes-A lottery for living space. Environ. Biol. Fishes Vol. 1978, 3, 85-102. [CrossRef]

196. Langille, M.G.I.; Zaneveld, J.; Caporaso, J.G.; Mcdonald, D.; Knights, D.; Reyes, J.A.; Clemente, J.C.; Burkepile, D.E.; Rebecca, L.; Thurber, V.; et al. Predictive functional profiling of microbial communities using 16S rRNA marker gene sequences. Nat. Biotechnol. 2013, 31, 814-821. [CrossRef] [PubMed]

197. Xu, Z.; Malmer, D.; Langille, M.G.I.; Way, S.F.; Knight, R. Which is more important for classifying microbial communities: Who's there or what they can do? ISME J. 2014, 8, 2357-2359. [CrossRef] [PubMed]

198. Kanehisa, M.; Sato, Y.; Kawashima, M.; Furumichi, M.; Tanabe, M. KEGG as a reference resource for gene and protein annotation. Nucleic Acids Res. 2016, 44, D457-D462. [CrossRef] [PubMed]

199. Yoon, J.H.; Park, S.E.; Kang, S.J.; Oh, T.K. Rheinheimera aquimaris sp. nov., isolated from seawater of the East Sea in Korea. Int. J. Syst. Evol. Microbiol. 2007, 57, 1386-1390. [CrossRef] [PubMed]

200. Nielsen, J.; Liesack, W.; Finster, K. Desulfovibrio zosterae sp. nov., a new sulfate reducer isolated from surface-sterilized roots of the seagrass Zostera marina. Int. J. Syst. Bacteriol. 1999, 49, 859-865. [CrossRef] [PubMed]

201. Cifuentes, A.; Antón, J.; Benlloch, S.; Donnelly, A.; Herbert, R.A.; Rodríguez-Valera, F. Prokaryotic diversity in Zostera noltiicolonized marine sediments. Appl. Environ. Microbiol. 2000, 66, 1715-1719. [CrossRef] [PubMed]

202. Alsaffar, Z.; Pearman, J.K.; Cúrdia, J.; Ellis, J.; Calleja, M.L.; Ruiz-Compean, P.; Roth, F.; Villalobos, R.; Jones, B.H.; Morán, X.A.G.; et al. The role of seagrass vegetation and local environmental conditions in shaping benthic bacterial and macroinvertebrate communities in a tropical coastal lagoon. Sci. Rep. 2020, 10, 13550. [CrossRef] [PubMed]

203. Kuo, J.; McComb, A.; Cambridge, M.L. Ultrastructure of the seagrass rhizosphere. New. Phytol. 1981, 89, 139-143. [CrossRef]

204. Novak, R. A study in ultra-ecology: Microorganisms of the seagrass Posidonia oceanica (L.) Delile. Mar. Ecol. 1984, 5, 143-190. [CrossRef]

205. Vohník, M.; Borovec, O.; Kolařík, M. Communities of Cultivable Root Mycobionts of the Seagrass Posidonia oceanica in the Northwest Mediterranean Sea Are Dominated by a Hitherto Undescribed Pleosporalean Dark Septate Endophyte. Microb. Ecol. 2016, 71, 442-451. [CrossRef] [PubMed]

206. Zheng, P.; Wang, C.; Zhang, X.; Gong, J. Community Structure and Abundance of Archaea in a Zostera marina Meadow: A Comparison between Seagrass-Colonized and Bare Sediment Sites. Archaea 2019, 2019, 1-11. [CrossRef]

207. Ettinger, C.L.; Eisen, J.A. Characterization of the Mycobiome of the Seagrass, Zostera marina, Reveals Putative Associations with Marine Chytrids. Front. Microbiol. 2019, 10, 1-13. [CrossRef]

208. Wagner, A.O.; Praeg, N.; Reitschuler, C.; Illmer, P. Effect of DNA extraction procedure, repeated extraction and ethidium monoazide (EMA)/propidium monoazide (PMA) treatment on overall DNA yield and impact on microbial fingerprints for bacteria, fungi and archaea in a reference soil. Appl. Soil Ecol. 2015, 93, 56-64. [CrossRef] 
209. Jones, M.B.; Highlander, S.K.; Anderson, E.L.; Li, W.; Dayrit, M.; Klitgord, N.; Fabani, M.M.; Seguritan, V.; Green, J.; Pride, D.T.; et al. Library preparation methodology can influence genomic and functional predictions in human microbiome research. Proc. Natl. Acad. Sci. USA 2015, 112, 14024-14029. [CrossRef]

210. Escobar-Zepeda, A.; De León, A.V.P.; Sanchez-Flores, A. The road to metagenomics: From microbiology to DNA sequencing technologies and bioinformatics. Front. Genet. 2015, 61, 1-15. [CrossRef] [PubMed]

211. Jünemann, S.; Sedlazeck, F.J.; Prior, K.; Albersmeier, A.; John, U.; Kalinowski, J.; Mellmann, A.; Goesmann, A.; von Haeseler, A.; Stoye, J.; et al. Updating benchtop sequencing performance comparison. Nat. Biotechnol. 2013, 31, 294-296. [CrossRef]

212. Quail, M.A.; Smith, M.; Coupland, P.; Otto, T.D.; Harris, S.R.; Connor, T.R.; Bertoni, A.; Swerdlow, H.P.; Gu, Y. A tale of three next generation sequencing platforms: Comparison of Ion Torrent, Pacific Biosciences and Illumina MiSeq sequencers. BMC Genom. 2012, 13, 1-13. [CrossRef]

213. Schloss, P.D.; Westcott, S.L.; Ryabin, T.; Hall, J.R.; Hartmann, M.; Hollister, E.B.; Lesniewski, R.A.; Oakley, B.B.; Parks, D.H.; Robinson, C.J.; et al. Introducing MOTHUR: Open-source, platform-independent, community-supported software for describing and comparing microbial communities. Appl. Environ. Microbiol. 2009, 75, 7537-7541. [CrossRef] [PubMed]

214. Bolyen, E.; Rideout, J.R.; Dillon, M.R.; Bokulich, N.A.; Abnet, C.C.; Al-Ghalith, G.A.; Alexander, H.; Alm, E.J.; Asnicar, F.; Bai, Y.B.; et al. Reproducible, interactive, scalable and extensible microbiome data science using QIIME 2. Nat. Biotech. 2019, 37, 852-857. [CrossRef] [PubMed]

215. Nilakanta, H.; Drews, K.L.; Firrell, S.; Foulkes, M.A.; Jablonski, K.A. A review of software for analyzing molecular sequences. BMC Res. Notes 2014, 7. [CrossRef] [PubMed]

216. Bailén, M.; Bressa, C.; Larrosa, M.; González-Soltero, R. Bioinformatic strategies to address limitations of 16rRNA short-read amplicons from different sequencing platforms. J. Microbiol. Methods 2020, 169. [CrossRef] [PubMed]

217. Balvočiute, M.; Huson, D.H. SILVA, RDP, Greengenes, NCBI and OTT-How do these taxonomies compare? BMC Genom. 2017, 18, 1-18. [CrossRef]

218. Yilmaz, P.; Parfrey, L.W.; Yarza, P.; Gerken, J.; Pruesse, E.; Quast, C.; Schweer, T.; Peplies, J.; Ludwig, W.; Glöckner, F.O. The SILVA and "all-species Living Tree Project (LTP)" taxonomic frameworks. Nucleic Acids Res. 2014, 42, 643-648. [CrossRef]

219. Wang, Q.; Garrity, G.M.; Tiedje, J.M.; Cole, J.R. Naïve Bayesian classifier for rapid assignment of rRNA sequences into the new bacterial taxonomy. Appl. Environ. Microbiol. 2007, 73, 5261-5267. [CrossRef] [PubMed]

220. Federhen, S. The NCBI Taxonomy database. Nucleic Acids Res. 2012, 40, 136-143. [CrossRef] [PubMed]

221. McDonald, D.; Price, M.N.; Goodrich, J.; Nawrocki, E.P.; Desantis, T.Z.; Probst, A.; Andersen, G.L.; Knight, R.; Hugenholtz, P. An improved Greengenes taxonomy with explicit ranks for ecological and evolutionary analyses of bacteria and archaea. ISME J. 2012, 6, 610-618. [CrossRef] [PubMed]

222. Johnson, J.S.; Spakowicz, D.J.; Hong, B.Y.; Petersen, L.M.; Demkowicz, P.; Chen, L.; Leopold, S.R.; Hanson, B.M.; Agresta, H.O.; Gerstein, M.; et al. Evaluation of $16 \mathrm{~S}$ rRNA gene sequencing for species and strain-level microbiome analysis. Nat. Commun. 2019, 10, 1-11. [CrossRef] [PubMed]

223. Franssen, S.U.; Gu, J.; Bergmann, N.; Winters, G.; Klostermeier, U.C.; Rosenstiel, P.; Bornberg-Bauer, E. Transcriptomic resilience to global warming in the seagrass Zostera marina, a marine foundation species. Proc. Natl. Acad. Sci. USA 2011, 108, 19276-19281. [CrossRef]

224. Davey, P.A.; Pernice, M.; Ashworth, J.; Kuzhiumparambil, U.; Szabó, M.; Dolferus, R.; Ralph, P.J. A new mechanistic understanding of light-limitation in the seagrass Zostera muelleri. Mar. Environ. Res. 2018, 134, 55-67. [CrossRef] [PubMed]

225. Caruso, G. Microbes and their use as Indicators of Pollution. J. Pollut. Eff. Control 2013, 1, 1-2. [CrossRef]

226. Cordier, T.; Lanzén, A.; Apothéloz-Perret-Gentil, L.; Stoeck, T.; Pawlowski, J. Embracing Environmental Genomics and Machine Learning for Routine Biomonitoring. Trends Microbiol. 2019, 27, 387-397. [CrossRef] [PubMed]

227. Borja, A.; Franco, J.; Pérez, V. A marine Biotic Index to establish the ecological quality of soft-bottom benthos within European estuarine and coastal environments. Mar. Pollut. Bull. 2000, 40, 1100-1114. [CrossRef]

228. Borja, A. Testing the efficiency of a bacterial community-based index (microgAMBI) to assess distinct impact sources in six locations around the world. Ecol. Indic. 2018, 85, 594-602. [CrossRef]

229. Muxika, I.; Borja, Á.; Bonne, W. The suitability of the marine biotic index (AMBI) to new impact sources along European coasts. Ecol. Indic. 2005, 5, 19-31. [CrossRef]

230. Aires, T.; Serrão, E.A.; Engelen, A.H. Host and environmental specificity in bacterial communities associated to two highly invasive marine species (genus Asparagopsis). Front. Microbiol. 2016, 7, 1-14. [CrossRef] [PubMed]

231. Serebryakova, A.; Aires, T.; Viard, F.; Serrao, E.A.; Engelen, A.H. Summer shifts of bacterial communities associated with the invasive brown seaweed Sargassum muticum are location and tissue dependent. PLoS ONE 2018, 13, e0206734. [CrossRef] [PubMed]

232. Huang, S.; Song, Q.; Li, Q.; Zhang, H.; Luo, X.; Zheng, Z. Damage of heavy metals to Vallisneria natans (V. natans) and characterization of microbial community in biofilm. Aquat. Toxicol. 2020, 225. [CrossRef] [PubMed] 